RECORDS ADMINISTRATION

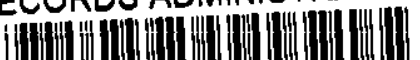

R0138976

$D P=430$

Metallurgy and Ceramics

Reactors - Power

AEC Research and Development Report

FABRICATION OF

URANIUM OXIDE FUEL ELEMENTS

by

G. R. Cole, A. S. Ferrara, and H. H. Kranzlein

Pile Materials Division

December 1959

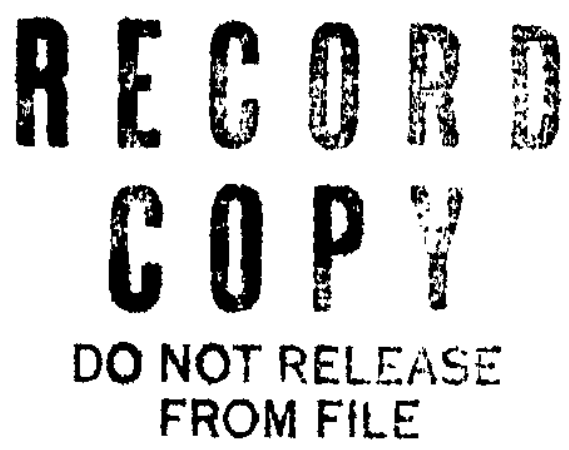

E. I. du Pont de Nemours \& Co.

Savannah River Laboratory

Aiken, South Carolina 
This report was prepared as an account of Government sponsored work. Ne1ther the United States, nor the Commlssion, nor any person acting on behalf of the Commission:

A. Makes any warranty or representation, expressed or implied, with respect to the accuracy, completeness, or usefulness of the information contained in this report, or that the use of any information, apparatus, method, or process disclosed in this report may not infringe privately owned rights; or

B. Assumes any 11abilities with respect to the use of, or for damages resulting from the use of any information, apparatus, method, or process disclosed in this report.

As used in the above, "person acting on behalf of the Commission" includes any employee or contractor of the commission, or employee of such contractor, to the extent that such employee or contractor of the Commission, or employee of such contractor prepares, disseminates, or provides access to, any information pursuant to his employment or contract with the Commission, or his employment with such contractor.

Printed in USA. Price $\$ 1.00$

Avallable from the office of Technical Services

U. S. Department of Commerce

Washington 25, D. C. 


$$
D P-430
$$

METALLURGY AND CERAMICS

REACTORS - POWER

(TID-4500, 15th Ed.)

\section{FABRICATION OF URANIUM OXIDE FUEL ELEMENTS}

by

G. Rolland Cole, Anthony S. Ferrara, and Harvard H. Kranzlein

December 1959

E. I. du Pont de Nemours \& Co.

Explosives Department - Atomic Energy Division

Technical Division - Savannah River Laboratory

Printed for

The United States Atomic Energy Commission

Contract AT $(07-2)-1$ 


\section{ABSTRACT}

Experimental fuel elements of $\mathrm{UO}_{2}$ clad in metallic sheaths were fabricated by swaging, rolling, and coextrusion. The effects of the type of $\mathrm{UO}_{2}$ and of the materials and dimensions of the sheath were investigated. Fused $\mathrm{UO}_{2}$ swaged in stainless steel tubing reached a maximum density of $93 \%$ of theoretical. 


\section{CONTENTS}

$\begin{array}{lr}\text { List of Figures } & 4 \\ \text { Introduction } & 5 \\ \text { Summary } & 5 \\ \text { Discussion } & 6 \\ \text { Background } & 6 \\ \text { Types of Uranium Oxide } & 7 \\ \text { Swaging of Rods } & 10 \\ \text { Fused UOz } & 12 \\ \text { Sintered PWR Pellets } & 13 \\ \text { PWR-Grade UOz } & 13 \\ \text { Steam-Oxidized UOz } & \\ \text { Influence of Sheath Characteristics } & 15 \\ \text { Swaging of Tubes } & 17 \\ \text { Two-Die Swager } & 22 \\ \text { Four-Die Swager } & 22 \\ \text { Rolling of Rods } & 23 \\ \text { Rolling of Ribbons } & 24 \\ \text { Coextrusion of Rods } & 27 \\ \text { B1bliography } & 31 \\ & 35\end{array}$

\section{LIST OF TABLES}

Table

\begin{tabular}{|c|c|}
\hline I & Grades of Arc-Fused $\mathrm{UO}_{2}$ \\
\hline II & Density of Fused $\mathrm{UO}_{2}$ after Swaging \\
\hline III & Effect of $\mathrm{UO}_{2}$ Particle Size on Density after Swaging \\
\hline IV & $\begin{array}{l}\text { Effect of Initial Density on Final Density and } \\
\text { Sheath Thickness }\end{array}$ \\
\hline $\mathrm{V}$ & Effect of Sheath Material on Density of Swaged $\mathrm{UO}_{2}$ \\
\hline VI & Effect of Wall Thickness on Density of Swaged $\mathrm{UO}_{2}$ \\
\hline VII & Density of $\mathrm{UO}_{2}$ in Rolled Rods \\
\hline VIII & Stratification in Flat-Rolled Specimens \\
\hline IX & Density of $\mathrm{UO}_{2}$ in Coextruded Rods \\
\hline
\end{tabular}




\section{LIST OF FIGURES}

Figure

Page

1 Arc-Fused $\mathrm{UO}_{2}$

2 Grades of Fused $\mathrm{UO}_{2}$

3 Swaging Behavior of Rods - Fused $\mathrm{UO}_{2}$

4 Swaging Behavior of Rods - PWR-Grade $\mathrm{UO}_{2}$

5 Effect of Particle Size on Swaging Behavior of PWR-Grade $\mathrm{UO}_{2}$

6 Effect of Initial Density on Swaglng Behavior of PWR-Grade $\mathrm{UO}_{2}$

14

7 Appearance of Cold-Swaged and Hot-Swaged PWR-Grade $\mathrm{UO}_{2} \quad 15$

8 Effect of Oxide Type on Swaging Behavior of Rods 16

9 Effect of Initial Diameter on Swaging Behavior of $\mathrm{UO}_{2}$ Rods

10 Effect of Initial Wall Thlckness on Swaging Behavior of $\mathrm{UO}_{2}$ Rods

11 Zircaloy-2-Clad Rod that Falled during Swaging

12 Zircaloy-2-Clad Rod Swaged to 50\% Reduction in Area

13 Longltudinal Section of Permanent End Plug before Swaging

21

14 Permanent End Plug after Swaging

21

15 Swaged Tubular Element

23

16 Rolled Rod Elements

25

17 Sheath Fallure of a Rolled Rod

18 Cross Sections of Swaged-and-Rolled Rods 26

19 Cross Section of Rolled Rod - Composite Sheath 26

20 Rolling Behavior of Ribbons - PWR-Grade $\mathrm{UO}_{2} \quad 27$

21 Rolling Behavior of Ribbons - Fused UO2 28

22 Cross Sections of Rolled Ribbons 29

23 Effect of Rod Diameter on $\mathrm{UO}_{2}$ Density in Rolled Ribbons 30

24 Twisted Ribbon Element * 31

25 Coextrusion Biliets 32

26 Typical Coextruded Rods 32

27 Radiographs of Coextruded Rods 33

28 Cross Section of Coextruded Rod 34 


\section{FABRICATION OF URANIUM OXIDE FUEL ELEMENTS}

\section{INTRODUCTION}

The Savannah River Laboratory is developing oxide fuel elements for heavy-water-moderated power reactors fueled with natural uranium. Although metalifc uranium is the first choice for the fuel material, it may have exposure limitations that make desirable the development of an oxide fuel element as a backup. The program is directed toward devising a fabrication process that is more attractive economically than the pressing and sintering process that is frequently used at the present time.

Fuel elements of $\mathrm{UO}_{2}$ can take varlous forms, but the simple rod form, or right circular cylinder, is the one most thoroughly proved and widely applied in power reactor service at present. The rod shape is resistant to deformation by internal pressure and is relatively easy to fabricate, but alternative shapes that have a higher surface-tovolume ratio, e.g., tubes and flat or twisted ribbons, may be more attractive if they can be produced cheaply and prove to be reliable in service.

There are a number of alternative processes for the fabrication of oxide fuel elements. Dense pellets of $\mathrm{UO}_{2}$ can be made by pressing, followed by high temperature sintering. The pellets are subsequently encased in a metal sheath to produce a fuel element. Swaging and rolling are processes that simultaneously densify the $\mathrm{UO}_{2}$ within a metal sheath and form the element to the final shape and size. Either swaging or rolling may produce clad fuel elements more economically than they can be produced by a pressing and sintering process.

This report summarizes the investigations at the Savannah River Laboratory from November 1957 to May 1959 on the fabrication of $\mathrm{UO}_{2}$ fuel elements by swaging, rolling, and coextrusion.

\section{SUMMARY}

Rotary swaging of rods and tubes, rolling of rods and ribbons, and coextrusion of rods were investigated for the fabrication of $\mathrm{UO}_{2}$ fuel elements.

Swaged rods represent the most attractive fabrication method and shape at the present stage of development. The densities that can be produced with various types of core and sheath materials are well known, and little further development would be required to define a production process. The best results were obtained by swaging small diameter rods of arc-fused $\mathrm{UO}_{2}$ in stainless steel sheathing. Rods were swaged to densities up to $93 \%$ of theoretical, and the control of diameter and wall thickness was satisfactory. 
Swaged tubes appear to be attractive, and most of the future work on this program will be concentrated on the swaging of tubular fuel elements. Oxide densities are comparable to those of rod elements. Technlques for removing the mandrel and for controlling the thickness of the annulus appear to be the next problems to be solved.

Roll forming produced rods and ribbons with $\mathrm{UO}_{2}$ densities from 86 to $88 \%$ of theoretical compared to $92 \%$ for swaged rods; the dimensions and shapes of the rolled specimens were poorly controlled. Problems remaining in the rod rolling process include sheath fallure when wall thicknesses of practical interest are employed, and bowing of the rods. Improvement in the design of the roll grooves, and the addition of roll guides might solve these problems. The maximum $\mathrm{UO}_{2}$ densities in rolled ribbons were lower than those of swaged or rolled rods, primarily because of sheath springback at large area reductions.

Coextruded rods were made with fused $\mathrm{UO}_{2}$ cores and aluminum alloy sheaths. The rods, coextruded at about $450^{\circ} \mathrm{C}$, had oxide densities substantially lower than those obtained by the other fabrication methods. It is anticipated that coextrusions at higher temperatures, $800^{\circ} \mathrm{C}$ and up, in suitable cladding materials would produce cores of higher densities.

For a given fabrication method and fuel shape the final $\mathrm{UO}_{2}$ density depended upon the type of $\mathrm{UO}_{2}$ used, the amount that the cross-sectional area was reduced in the fabrication process, and the nature of the sheath material. Variables such as specimen size and sheath thickness had minor effects.

\section{DISCUSSION}

\section{BACKGROUND}

Dimensional stability, resistance to coolant corrosion, high thermal conductivity, good nuclear reactivity, and low cost are characteristics desired in a power reactor fuel material. Contemporary $\mathrm{UO}_{2}$ fuel elements meet the first two requirements, but are somewhat lacking with respect to the remaining three. Extensive irradiation tests on sintered pellets of $\mathrm{UO}_{2}$ have shown that volume increases are negligible even at high burnup. $(1,2)$ Uranium dioxide, having a cubic lattice, is isotropic and thus is not subject to the dimensional changes under thermal cycling or irradiation that have been exhibited by metalifc uranium. Uranium dioxide is not attacked chemically by deoxygenated water at high temperature. $(3,4)$ Dilution by oxygen atoms lowers the nuclear reactivity of uranium, but unenriched $\mathrm{UO}_{2}$ is usable if zirconium cladding and heavy water moderation are employed. (2) The thermal conductivity of $\mathrm{UO}_{2}$ is low, only one-third that of metailic uranium at ordinary temperatures, and it decreases with increasing temperature; $^{(5-8)}$ however, the low thermal conductivity of the oxide is partially compensated by its high melting point. To achieve low cost nuclear power there is need to lower the capital cost per unit of 
1nstalled power capac1ty. and to reduce the fuel costs. The program discussed in this report was aimed primarily at the development of a low cost fuel element.

Uranium dioxide fuel elements made by encasing pressed and sintered pellets within metal tubing are generally accepted for power reactor use. Their reliability has been demonstrated in the Westinghouse pressurized water reactor (PWR) and in the Vallecitos boiling water reactor of the General Electric Company (VBWR); oxide fuel elements are specifled for several reactors not yet in operation (the Dresden reactor, the Nuclear Power Demonstration reactor, and the Nuclear Ship Savannah reactor, for example).

Fabrication methods that densify the $\mathrm{UO}_{2}$ and form the clad fuel element in one operation, such as swaging and rolling, are potentially low cost processes; a proven process, together with a reliable cost estimate, is not yet avallable, however. Swage fabrication of $\mathrm{UO}_{2}$ fuel rods has been investigated at the Hanford Atomic Products Operation $(s)$, at Chalk River ${ }^{(10)}$, and at the Savannah River Laboratory.

High bulk density is a desirable feature in unenriched $\mathrm{UO}_{2}$ fuel. It is probably the most important single index of $\mathrm{UO}_{2}$ fuel quality and, as such, recelves considerable attention in this report. Nuclear reactivity can be increased by maximizing the density, or the number of uranium atoms per unit volume. High density oxide, in which the number of pores or volds is low, has greater thermal conductivity. Postirradiation studies have shown that release of fission product gases, which can cause pressure bulldup in the element or progressive decrease in heat transfer capability, increases with decreasing $\mathrm{UO}_{2}$ density. $(1,2)$

\section{TYPES OF URANIUM OXIDE}

The highest swaged densities observed in this investigation were obtained with arc-fused $\mathrm{UO}_{2}$. Th1s $\mathrm{UO}_{2}$ was fused at the Chippawa, ontario, Plant of the Norton Company by a method similar to that commonly employed to fuse alumina or magnesia. The two lots of product recelved consisted mostly of irregular chunks ranging in size from $1 / 2$ to 3 inches in the greatest Iinear dimension.

The fused $\mathrm{UO}_{2}$ varled in quality from piece to piece, and some of the larger chunks varied in quality within a single piece. For example, two pleces containing large, shiny crystals adjacent to regions of rough material are shown in Figure 1 . After the $\mathrm{UO}_{2}$ chunks were crushed Into smaller pieces, they were graded by appearance. Typical graded pleces are shown in Figure 2; a brief description of each grade is given in Table $I$. 

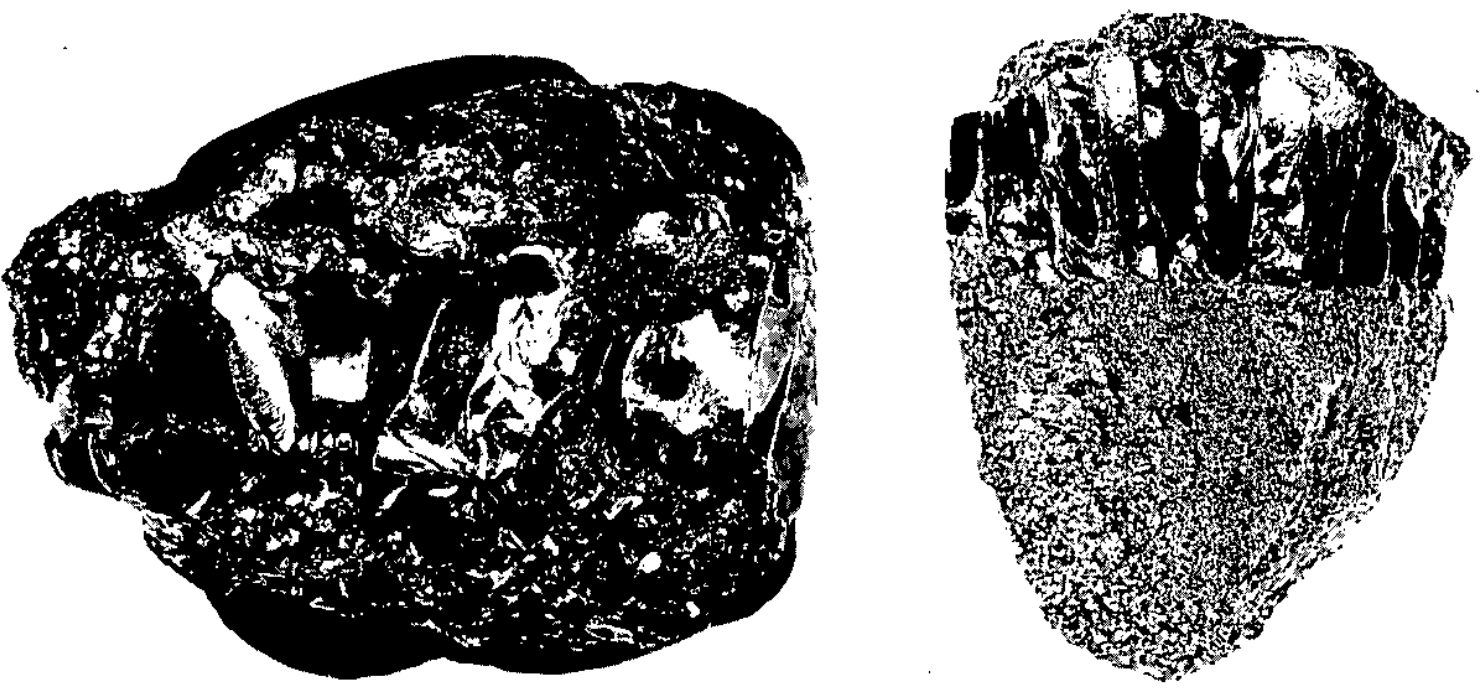

Nog. 15538

$\operatorname{Meg} 2.5 X$

Neg. 21377

Mog. .85X

FIGURE 1 - ARC. FUSED $\mathrm{UO}_{2}$

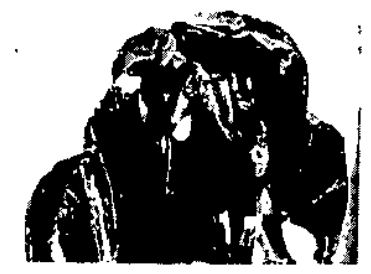

Neg. 21837 Mag. .85X

Grode 1.

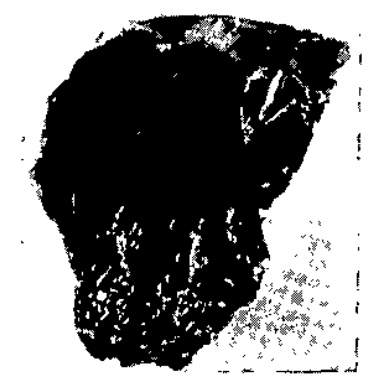

Neg. 21845 Mag. 1.3X

Grade 2+

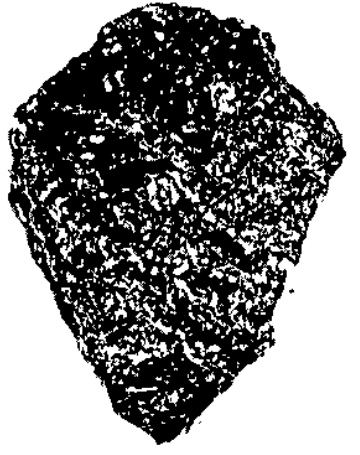

Nog. 21838

Grade 2

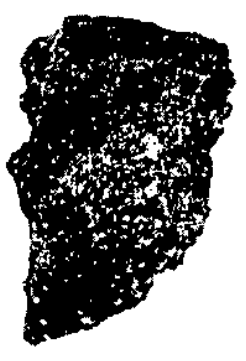

Mag. .85X

Grade 2.

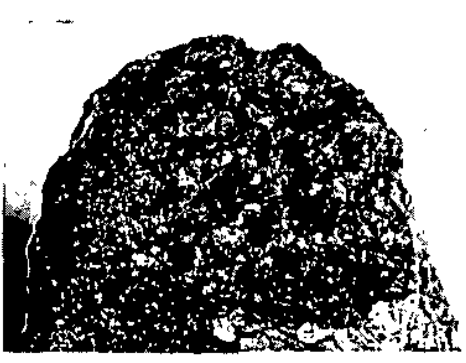

Nog. 21837

Mag. . $85 \mathrm{X}$

Grade 5

FIGURE 2 - GRADES OF FUSED $\mathrm{UO}_{2}$ 
TABLE I

Grades of Arc-Fused $\mathrm{UO}_{2}$

Grade

Number

1

$1 "$ Select"

$2+$

$2-$

3

4

5 Shiny, but with sur-

face craters

Smooth and shiny, with good crystal faces

Smooth, but not so shiny

Rough surfaces

Rough, dull surfaces

Crushing fines (a mixture of the other grades)

Powder at the bottom of the shipping container
Representative

Chunk Density, of of theoretical

Average
100

Oxygen-toUranium Ratio Lot $1^{(a)}$ Lot $2^{(b)}$

$2.058 \quad 2.047$ 2.014

98

2.142

2.096

95

2.145

2.063

86

2.192

2.039

$-$

2.193

$-$

2.206

93

2.113

(a) Lot 1 consisted of a single fusion, 300 lb of product.

(b) Lot 2 consisted of a series of 26 fusions, 16,800 $1 \mathrm{~b}$ of product. The evaluation of Lot 2 is not yet complete.

\section{TABLE II}

Density of Fused $\mathrm{UO}_{2}$ after Swaging

Minus 20-mesh $\mathrm{UO}_{2}$ in stainless steel cladding

Inftial diameter $=5 / 8$ inch

Initial wall thickness $=0.035$ inch

$\mathrm{UO}_{2}$ area reduction $=49 \%$

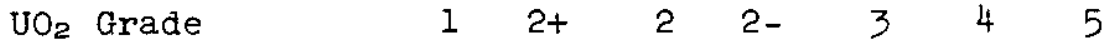

(described in

$2.14 \quad 2.08$

Table I)

$\mathrm{UO}_{2}$ Density

\% of theoretical

$\begin{array}{lllllll}92 & 91 & 92 & 91 & 92 & 85 & 91\end{array}$ 
Much of the fused oxide contained excess oxygen. Analyses, summarized In Table $I$, showed ratios of oxygen to uranium that ranged from 2.00 to 2.25 (corresponding to $\mathrm{UO}_{2} .00$ and $\mathrm{UO}_{2} .25$ ). The theoretical, or $\mathrm{X}$-ray, density of uranium oxide increases from 10.97 to 11.3 as the $0 / 0$ ratio increases from 2.00 to 2.25 . (11) The variations involved are relatively small, and for convenience all fabricated oxide densities are reported in terms of "per cent of theoretical" and are based on the theoretical density of stolchiometric $\mathrm{UO}_{2}\left(10.97 \mathrm{~g} / \mathrm{cm}^{3}\right)$. Excess oxygen is thought to impair the in-pile performance of the fuel elements, (2) but should have little effect on the results of fabrication studies at ordinary temperatures.

The carbon and iron contents of samples ranged from $<50$ to $200 \mathrm{ppm}$ and from zero to $700 \mathrm{ppm}$, respectively. Carbon, present as $\mathrm{UC}$ or $\mathrm{UC}_{2}$, is susceptible to attack by hot water, and thus impairs the over-all corrosion resistance. Iron is a neutron absorber and therefore is an undesirable impurity.

Other types of uranium oxide were investigated.

PWR-grade powder Produced by the reduction of $\mathrm{UO}_{3}$. The material was supplied by the Uranium Division of the Mallinckrodt Chemical Works.

Sintered pellets Reject pellets from the Bettis Plant production for the PWR. The pellets had a sintered density of about $93 \%$ of theoretical and were crushed to pass a 20 -mesh sleve before swagling.

Steam-oxidized uranium Produced by oxidation of uranium metal in steam at a pressure of $125 \mathrm{ps} 1$ and a temperature of $170^{\circ} \mathrm{C}$. The product was a fluffy powder with an $0 / 0=2.19$.

\section{SWAGING OF RODS}

Most of the experimental effort was concentrated on swaged rods, and higher $\mathrm{UO}_{2}$ densities and better control were achieved with the swaged rod elements than with other fabrication methods and fuel shapes. For example, $\mathrm{UO}_{2}$ densities up to $93 \%$ of theoretical were obtained by swaging fused $\mathrm{UO}_{2}$ through an area reduction of $50 \%$; the stainless steel sheathing was 0.035 inch thick and 0.625 inch in diameter initially. One series of six similar rods, with fused $\mathrm{UO}_{2}$ in 0.0325 -inch-thick stainless steel, was swaged from 0.750 -inch inftial diameter to 0.575 -inch final diameter with the following results and ranges: final diameter $=0.575 \pm 0.002$ Inch, sheath thickness $=0.0325 \pm 0.001$ inch, and $\mathrm{UO}_{2}$ density $=90.8$ $\pm 0.8 \%$ of theoretical.

Rod shapes were made by loading $\mathrm{UO}_{2}$ into metal tubing, after which the cross-sectional area was reduced by swaging. In most cases the $\mathrm{UO}_{2}$ powder was contained in the tubing by rubber end plugs. Specimen dlameter, or cross-sectional area, was reduced by passes through progressively smaller dies in the swaging machine. The area reduction of a specimen is defined by the formula

Area reduction $=($ Initial area - Final area $) /($ Initial area $)$ 
Most of the swaging experiments were performed with a two-die swaging machine, Fenn Model 6F. A few experiments were performed with a Fenn Model $4 \mathrm{~F}$ swaging machine of the four-die type.

The reduction in cross-sectional area of the rod* densified the $\mathrm{UO}_{2}$, changed the thickness of the metal sheath, and elongated the rod. Figure 3 shows these changes as functions of area reduction for fused $\mathrm{UO}_{2}$. At small area reductions the $\mathrm{UO}_{2}$ densified easily; the $\mathrm{UO}_{2}$ provided little support for the metal sheath, which increased in thickness without elongation as an empty tube does during swaging. At area reductions between 20 and $40 \%$, the $\mathrm{UO}_{2}$ became more dense and began to resist further reduction, thinning the sheath and causing the rod to elongate. For fused $\mathrm{UO}_{2}$, a maximum density was reached at an area reduction of about $40 \%$. Further reduction served only to elongate the rod and to thin the sheath at an increased rate. The comparable behavior for PWR-grade $\mathrm{UO}_{2}$ (shown in Figure 4) differs from the fused oxide in that the density continued to rise at area reductions above $40 \%$. The area reduction for both cases was limited to $68 \%$ by the range of die sizes avallable.

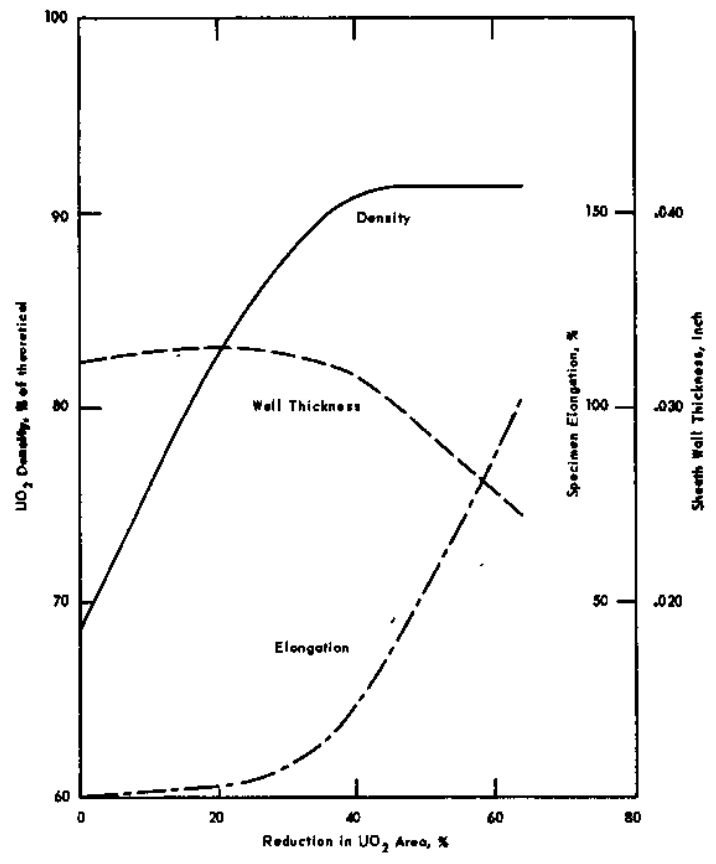

FIGURE 3 - SWAGING BEHAVIOR OF RODS - FUSED UO,

Type 316 Stainless Steel Sheath; Initial Rod Diameter $=0.750$ inch, Wall Thickness $=0.0325$ inch

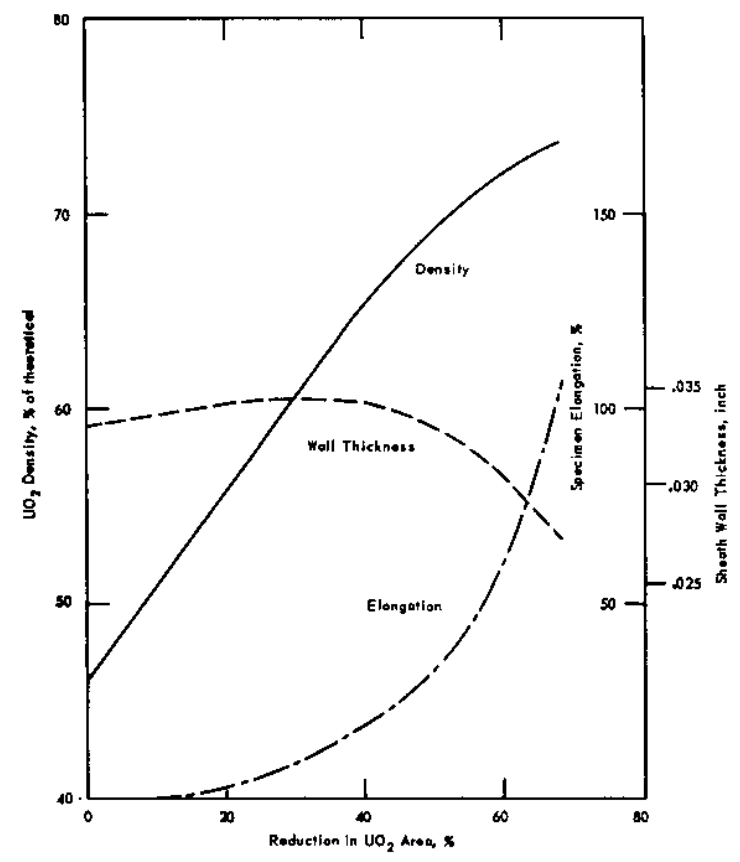

FIGURE 4 - SWAGING BEHAVIOR OF RODSPWR - GRADE UO,

Typo 316 Stainless Steel Sheath; Initial Rod Diameter $=0.750$ inch, Wall Thiekness $=0.033$ inch

*The word that describes the shape, e.g., rod, refers to the $\mathrm{UO}_{2}$ itself. The oxide is always contained within a metal tube when fabricated by this means. 
The density obtained for a given reduction in area depended greatly on the type of uranium oxide. Fused $\mathrm{UO}_{2}$ reached the highest maximum density, 93\% of theoretical, followed by crushed, sintered pellets with $89 \%$, steam-oxidized material with $80 \%$, and PWR-grade oxide with $75 \%$.

FUSED UO2

The various "grades" of fused $\mathrm{UO}_{2}$, with the exception of Grade 4, could be swaged to approximately equal densities despite the fact that the inftial as-fused densities of the individual chunks varled from grade to grade (compare Tables I and II, page 9). The initial differences in density caused by the presence of macroscopic holes in some of the chunks were minimized by the pulverizing and swaging operations, which reduced the chunks to particles of 0.03 inch or less in size. Grade 4 was the designation for the oxide fines that lay on the bottom of the shipping drum in the form of powder.

The particle size to which the fused $\mathrm{UO}_{2}$ was pulverized influenced the swaged density only slightly. The fused $\mathrm{UO}_{2}$ was quite friable, so the larger particles fractured easily to give efficient packing during swaging. The swaged densities were slightly lower when the maximum particle size was less than 70 mesh. The data are listed in Table III. The density results are for a complete range of particle sizes in each case, with only the maximum particle size being specifled. The passfractions were employed instead of specific cuts because the results have greater practical significance. Extensive sieve sizing and recycling of rejected fractions would be costly in production.

\section{TABLE III}

Effect of $\mathrm{UO}_{2}$ Particle Size on Density after Swaging

Grade No. 2, fused $\mathrm{JO}_{2}$ in stainless steel sheathing, Type 316 Initial diameter $=5 / 8$ inch Initial wall thickness $=0.035$ inch $\mathrm{UO}_{2}$ area reduction $=52 \%$

There was a range of particle sizes in each case; only the maximum particle size is specified.

\begin{tabular}{ccc}
$\begin{array}{c}\text { Sieve Size, } \\
\text { mesh }\end{array}$ & $\begin{array}{c}\text { Size of Largest } \\
\text { Particle, Inch }\end{array}$ & $\begin{array}{c}\mathrm{UO}_{2} \text { Density, } \\
\text { of theoretical }\end{array}$ \\
\cline { 1 - 1 }-6 & 0.132 & 91.6 \\
-10 & 0.0787 & 91.6 \\
-12 & 0.0661 & 91.3 \\
-16 & 0.0469 & 91.8 \\
-20 & 0.0331 & 91.6 \\
-40 & 0.0165 & 91.5 \\
-70 & 0.0083 & 90.8 \\
-120 & 0.0049 & 90.2 \\
& $-12-$ &
\end{tabular}


The influence of inftial packed density on final swaged density was minimized by moderate overswaging, but the constancy of final density was partially offset by variations in final sheath thickness; the applicable data for fused $\mathrm{UO}_{2}$ are shown in Table IV.

\section{$\underline{\text { TABLE IV }}$}

Effect of Initial Density on Final Density and Sheath Thickness

Grade No. 2 fused $\mathrm{UO}_{2}$ crushed to minus 20 mesh

Stainless steel sheath, inftially $5 / 8$ inch in diameter and 0.035 inch thick

$\mathrm{UO}_{2}$ area reduction $=52$ to $54 \%$

$\mathrm{UO} 2$ Density,

Final

\begin{tabular}{|c|c|c|}
\hline $\begin{array}{l}\text { of of the } \\
\text { Inttial }\end{array}$ & $\frac{\text { etical }}{\text { Final }}$ & $\begin{array}{c}\text { Sheath Thlckness, } \\
\text { inch }\end{array}$ \\
\hline 61.2 & 92.8 & 0.0314 \\
\hline 64.2 & 93.0 & 0.0309 \\
\hline 66.6 & 92.8 & 0.0303 \\
\hline .5 & 92.7 & 0.0293 \\
\hline
\end{tabular}

\section{SINTERED PWR PELLETS}

Relatively little swaging was performed with sintered and crushed PWR pellets. A density of $89 \%$ of theoretical was obtalned with sintered pellets crushed to pass 20 mesh and contained in Type 316 stainless steel tubing. The rod diameter was reduced from 0.625 to $0.44 \mathrm{inch}$, while the wall thickness diminished from 0.035 to 0.031 inch.

PWR-GRADE $\mathrm{UO}_{2}$

The PWR-grade $\mathrm{UO}_{2}$ had swaging characteristics similar to the fused $\mathrm{UO}_{2}$ with two exceptions: the maximum density obtained was much lower, $75 \%$ compared with $93 \%$ of theoretical, and the density continued to increase slightly even at the highest area reduction attained.

The effects of particle-size distribution on initial packed density, swaged denstty, and sheath thickness for PWR-grade $\mathrm{UO}_{2}$ in stainless steel are shown in Figure 5. PWR-grade $\mathrm{UO}_{2}$ was separated into -200-mesh and +200 -mesh fractions, and the swaging behaviors of the fractions were compared with that of the as-recelved powder. The packing and swaging characteristics of the -200 -mesh fraction were very similar to those of the as-received oxide, but the +200 -mesh oxide packed and swaged to lower densities. Superficlally, this appears to be a reversal of the effect observed for the fused $\mathrm{UO}_{2}$, Table III, where the smaller particle sizes swaged less well, but there were important differences in the average size, brittleness, and toughness of the particles concerned. A wide distribution of particle sizes was present in the as-received and the -200 -mesh samples, while the +200 mesh, which normally made up about 35\% of the PWR-grade powder, denslfied less well because of its limited distribution of particle sizes. Furthermore, the PWR-grade 
oxide particles were too small and tough (for their size) to overcome an unfavorable size distribution by fracturing and fitting together as did the fused $\mathrm{UO}_{2}$.

It might appear that the difference in swaged density between the +200 mesh and the as-received FWR-grade $\mathrm{UO}_{2}$ could be explained solely by the difference in initial packing density, but the effect of initial density alone was not sufficient to account for the difference in final swaged density shown in Figure 5. Specimens containing 1dentical. samples of $\mathrm{UO}_{2}$, deliberately packed to different initial densities, reached essentially equal final densities when swaged through a $60 \%$ area reduction, as shown in Figure 6.

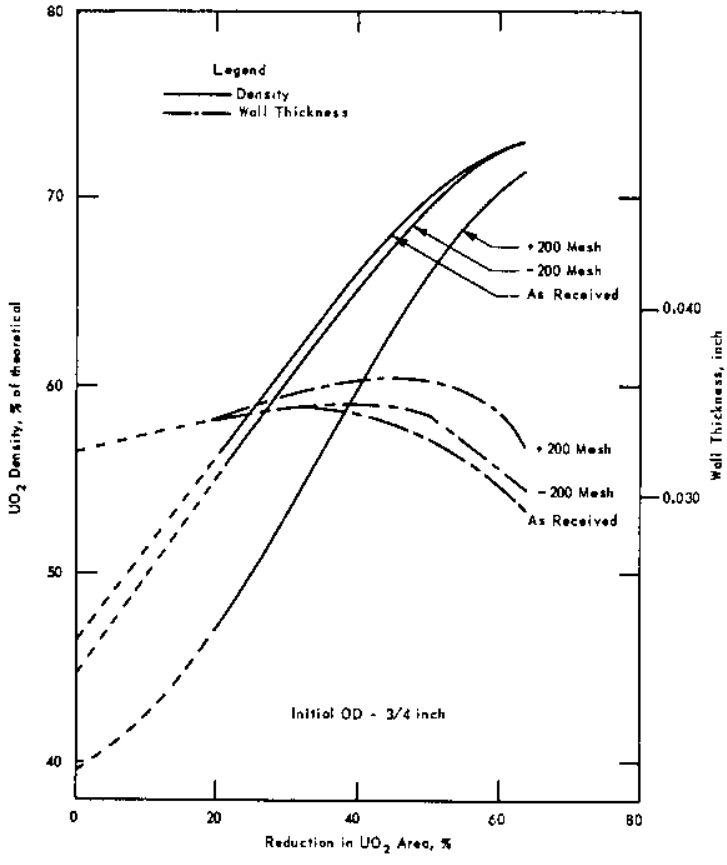

FIGURE 5 - EFFECT OF PARTICLE SIZE ON SWAGING BEHAVIOR OF PWR-GRADE UO, Rods Sheathed in Type 316 Stainless Steel

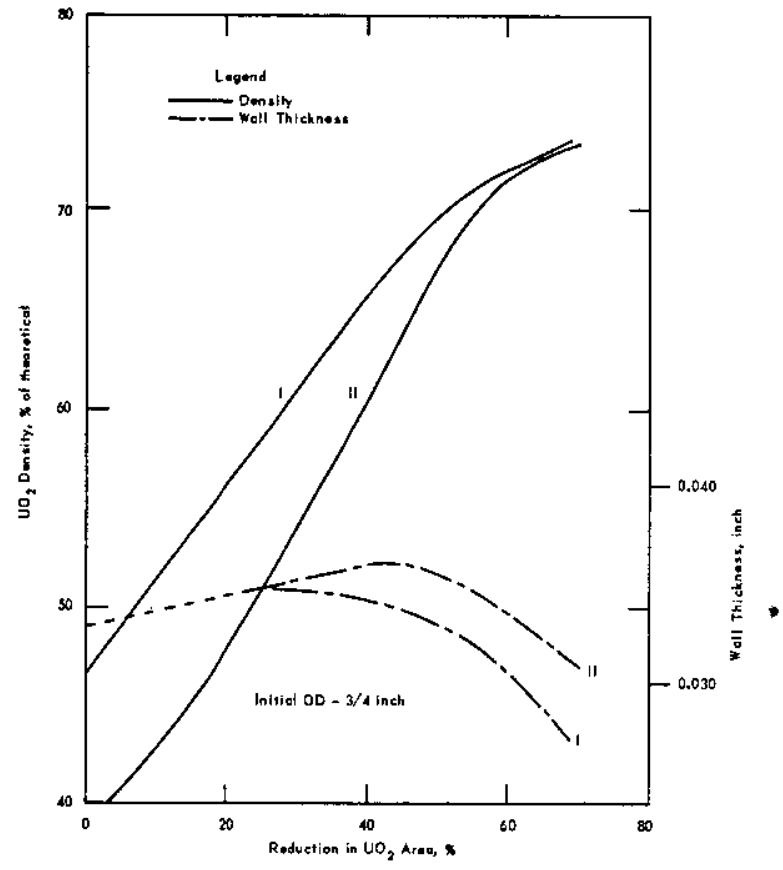

FIGURE 6 - EFFECT OF INITIAL DENSITY ON SWAGING BEHAVIOR OF PWR-GRADE UO PWR - Grade $\mathrm{UO}_{2}$ Rods Sheathed in Type 316 Stainless Steel

PWR-grade $\mathrm{UO}_{2}$ swaged to a greater density at high temperature than it did at room temperature, but still. it was less dense than fused $\mathrm{UO}_{2}$ swaged at room temperature. The $\mathrm{PWR}$-grade $\mathrm{UO}_{2}$, loaded in 0.065-inchwall stainless steel tubing, was swage-reduced from 0.750 -inch diameter to 0.533 or 0.500 inch at room temperature and then was reduced in two passes to 0.435 -inch diameter at a nominal temperature of $600^{\circ} \mathrm{C}$. The true temperature was below the nominal temperature because approximately 30 seconds elapsed between the removal of the piece from the furnace and the swaging operation. The final $\mathrm{UO}_{2}$ densities were approximately $80 \%$ of theoretical for the pleces swaged hot, compared to a density of $75 \%$ of theoretical reached by similar specimens swaged at room temperature. Higher densities have been obtained with hot-swaged specimens of smaller diameter at the Hanford 
Laboratories. (12) Local variations in sheath wall thickness were apparent after hot swaging. The sheaths ruptured when specimens with 0.035-inch stainless steel cladding were hot swaged. The hot-swaged $\mathrm{UO}_{2}$ had a more coherent, harder appearance than did cold-swaged $\mathrm{UO}_{2}$ (see the comparison in Figure 7). Although the swaging temperature of $600^{\circ} \mathrm{C}$ was far below that appropriate for sintering, about $1600^{\circ} \mathrm{C}$, the combination of high temperature and high swaging pressures may have produced an effect akin to sintering. Effective densification was achieved by a similar combination of less-than-sintering temperature and high pressure in hot pressing experiments.

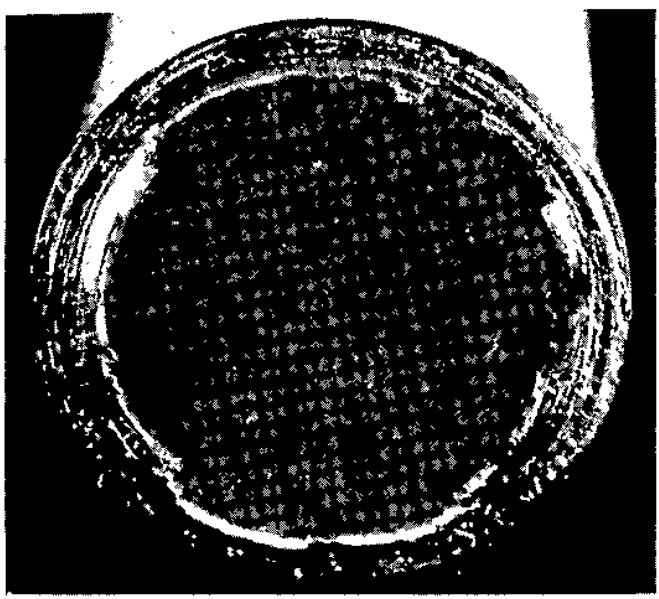

Neg. 21846

Mag. 5.7X

a. Swaged at Room Temperature

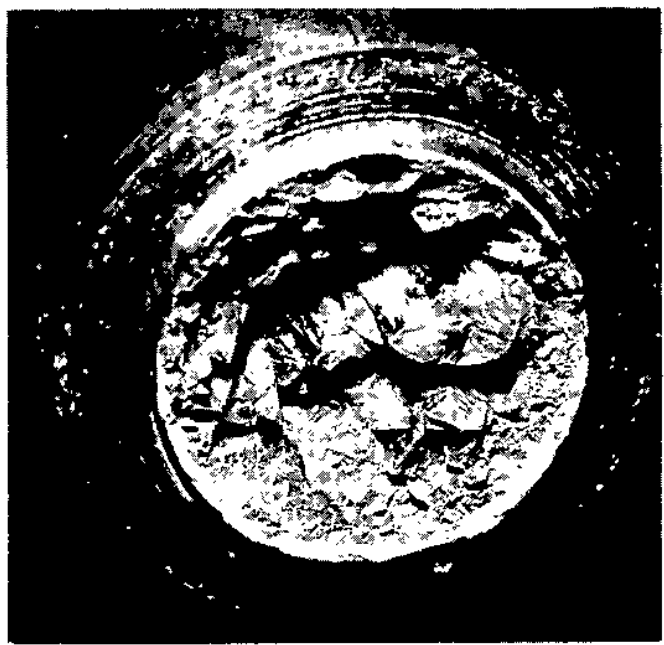

Neg. 17053

Mag. 5.7X

b. Swaged at a Nominal Temperature of $600^{\circ} \mathrm{C}$

FIGURE 7 - APPEARANCE OF COLD-SWAGED AND HOT-SWAGED PWR-GRADE UO 2 
The change in density and the thickening of the sheath during swaging were relatively greater for the steam-oxidized $\mathrm{UO}_{2}$ than for the other oxides investigated. The swaging behaviors of steam-oxidized and PWR-grade $\mathrm{UO}_{2}$ are compared in Figure 8 . Steam-oxidized $\mathrm{UO}_{2}$ packed to a lower density and swaged to a higher density than did PWR-grade oxide. The important difference lies in the nature of the individual particles. Uranium oxide produced by the steam oxidation of uranium metal consists of comparatively dense platelets $\{14$ that pack inefficlently, but break up readily and pack tightly under the vibration and pressure of swaging. This behavior is in marked contrast to that of the PWR-grade $\mathrm{UO}_{2}$, which has individual particles that are more regular in over-all shape, but less dense than the steam-oxidized material.

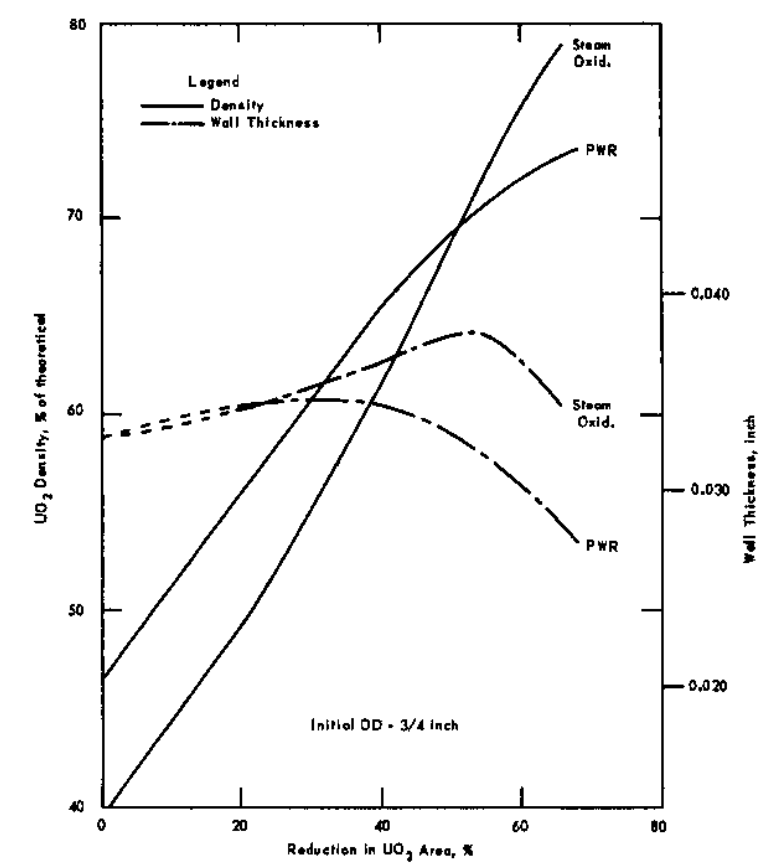

FIGURE 8 - EFFECT OF OXIDE TYPE ON SWAGING BEHAVIOR OF RODS

\section{$\mathrm{UO}_{2}$ Rods Sheathed in Type 316 Stainless Stoel}


Higher swaged densities were reached with uranium oxide in stainless steel or Zircaloy-2 sheaths than in aluminum or carbon steel sheaths. Presumably, the sheath materials with the higher yield strengths flowed less readily and thus maintained a higher maximum pressure on the $\mathrm{UO}_{2}$ during swaging. High area reductions were not obtained with the aluminum sheathing material because it split after a few passes through the swager. Table $V$ compares the densities obtained with fused oxide and PWR-grade oxide in the various sheath materials.

\section{TABLE V}

Effect of Sheath Material on Density of Swaged $\mathrm{UO}_{2}$

Initial rod diameters $=3 / 4$ inch

Inttial wall thicknesses $=0.033$ inch for stalnless steel

0.022 inch for Zircaloy-2

0.065 inch for carbon steel

0.035 inch for aluminum

\begin{tabular}{|c|c|c|c|c|}
\hline Core Material & Sheath Material & $\begin{array}{c}\mathrm{UO}_{2} \text { Area } \\
\text { Reduction, } \\
\%\end{array}$ & $\begin{array}{l}\mathrm{UO}_{2} \text { Density, } \% \\
\text { of theoretical }\end{array}$ & $\begin{array}{l}\text { Comparable } \\
\mathrm{UO}_{2} \text { Density } \\
\text { in Stain- } \\
\text { less Steel }\end{array}$ \\
\hline \multirow[t]{3}{*}{$\begin{array}{l}\text { Fused } \mathrm{UO}_{2} \\
(-20 \text { mesh })\end{array}$} & $\begin{array}{l}\text { Sta1nless Steel, } \\
\text { Type } 316\end{array}$ & 50 & 91.5 & - \\
\hline & Zircaloy-2 & 44 & 91.5 & 91.5 \\
\hline & $\begin{array}{l}\text { A luminum, Type } \\
6063\end{array}$ & 49 & $87 \cdot 5$ & 91.5 \\
\hline \multirow[t]{3}{*}{$\begin{array}{l}\text { PWR-grade } \mathrm{UO}_{2} \\
\text { (as-recelved) }\end{array}$} & $\begin{array}{l}\text { Stainless Stee1, } \\
\text { Type } 316\end{array}$ & 68 & 74 & - \\
\hline & Zircaloy-2 & 42.5 & 64.5 & 66.5 \\
\hline & Carbon Steel & 71 & 71 & 74 \\
\hline
\end{tabular}


Sheath dimensions, e.g., initial diameter and thickness, had a slight influence on the final $\mathrm{UO}_{2}$ density. Oxide density after swaging was slightly lower for the larger initial diameters. Figure 9 shows this effect for both fused $\mathrm{UO}_{2}$ and $\mathrm{PWR}-\mathrm{grade} \mathrm{UO}_{2}$. The data do not extend to the same maximum reductions for the different diameters because the extent of diameter reduction was limited by the size range of the swaging dies. For fused $\mathrm{UO}_{2}$ swaged in stainless steel, there was a difference of about $1 \%$ of theoretical density between specimens of 0.032 - and 0.007 -inch wall (Table VI). The density results for PWRgrade $\mathrm{UO}_{2}$ in 0.022 - and 0.033 -inch sheaths were essentially indistinguishable, while 0.066 -inch wall specimens reached a density about 1\% higher (Figure 10). The diameter effect was more important than the wall thickness effect. For example, In Figure 9, a comparison of results at an area reduction of $68 \%$ shows a density decrease of $2 \%$ of theoretical for a 33\% larger initial diameter, but Figure 10 Indicates a density decrease of only about $1 \%$ of theoretical for a $50 \%$ decrease in initial wall thickness. These data indicate that the influence of sheath dimensions on density is not simply a matter of diameter-to-wall-thickness ratio.

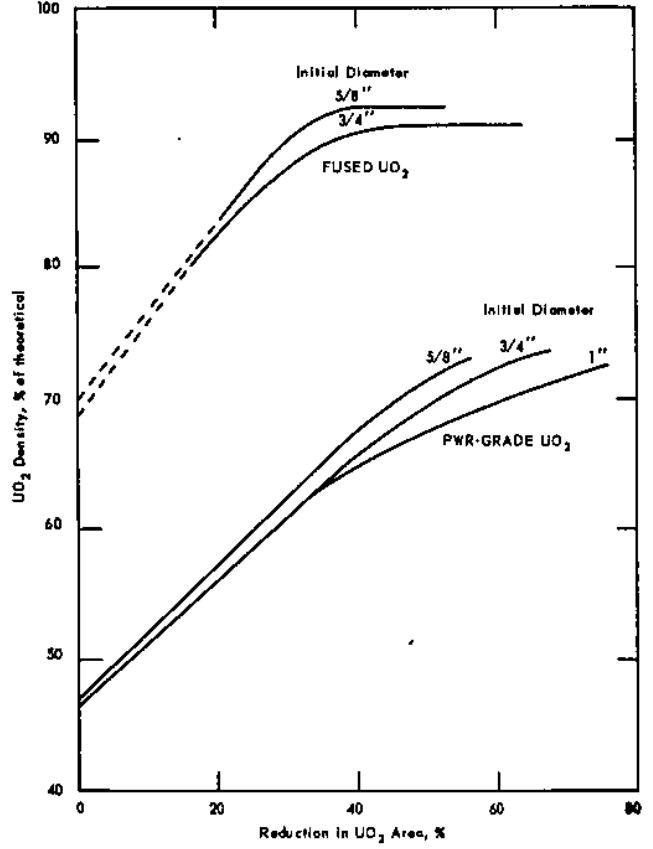

FIGURE 9 - EFFECT OF INITIAL DIAMETER ON SWAGING BEHAVIOR OF $\mathrm{UO}_{2}$ RODS

$\mathrm{UO}_{2}$ Sheathed in Type 316 Stainless Steel

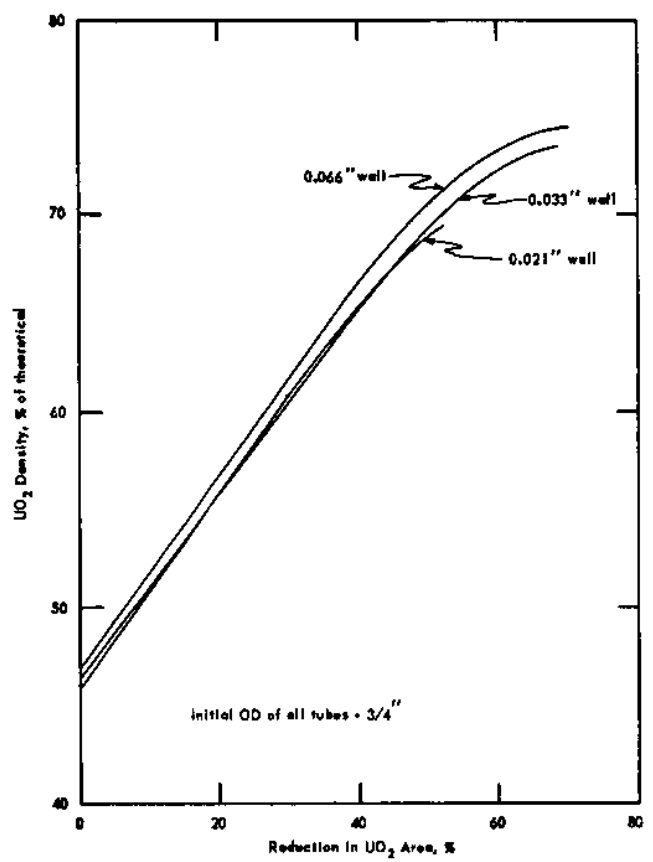

FIGURE 10 - EFFECT OF INITIAL WALL THICKNESS ON SWAGING BEHAVIOR OF $\mathrm{UO}_{2}$ RODS

PWR - Grade UO 2 Sheathed in Typo 316 Stainless Steol 


\section{TABLE VI}

\section{Effect of Wall Thickness on Density of Swaged $\mathrm{UO}_{2}$}

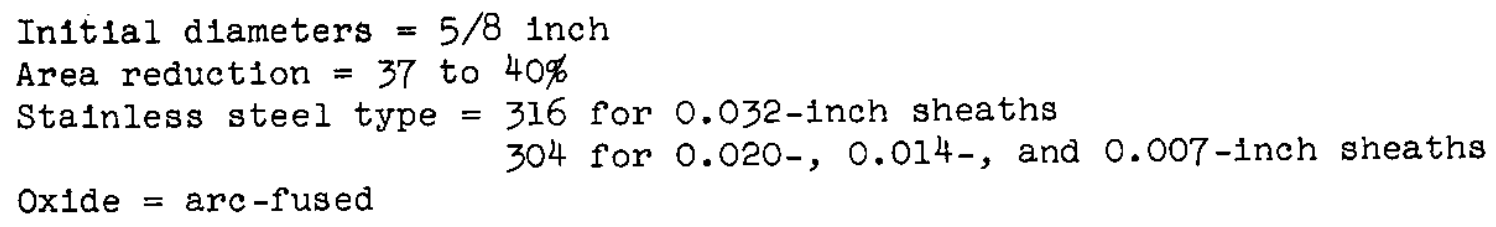

Sheath Thickness, Inch

0.032

0.020

0.014

0.007
$\mathrm{UO}_{2}$ Density, \% of theoretical

91.2

90.8

90.4

90.5

Wrinkling at the ends of the specimens sometimes occurred with thin sheaths, but proper choice of end plug material or improved design minimized such wrinkling. This behavior was particularly troublesome with sheaths of 0.022 -inch Zircaloy-2 and 0.014 - and 0.007 -inch stainless steel. Replacing the customary rubber end plugs with a mixture of rubber cement and iron filings or sand greatly reduced the sheath wrinkling. This composition end plug material was loaded to the end of the specimen to provide sheath support.

A falled Z1rcaloy-2 sheath is shown in Figure 11.

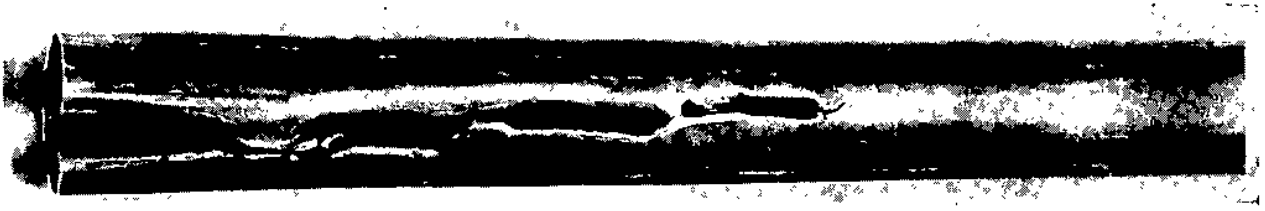

Neg. 16757

Actual Size

FIGURE $\|$ - ZIRCALOY-2-CLAD ROD THAT FALLD DURING SWAGING 
The $\mathrm{UO}_{2}$ was contained in the specimen by rubber end plugs that left about 2 inches of sheath unsupported at each end of the specimen. Similar end closures with stainless steel cladding of 0.035 -inch thickness were entirely satisfactory, but the 0.022-inch-thick Zircaloy-2 cladding cracked over the unsupported region. The crack started at the open end, crossed the rubber end plug, and reached the $\mathrm{UO}_{2}$, terminating the experiment. Properly designed metal end plugs, welded flush with the specimen ends, provided sufficlent sheath support to permit swaging through a core area reduction of $50 \%$. The proper end plug design was achleved by making the metal end plugs strong enough to provide support for the sheath and to contain the $\mathrm{UO}_{2}$, but weak enough to be reduced in dlameter without cutting through the sheath. A sample is shown in Figure 12.

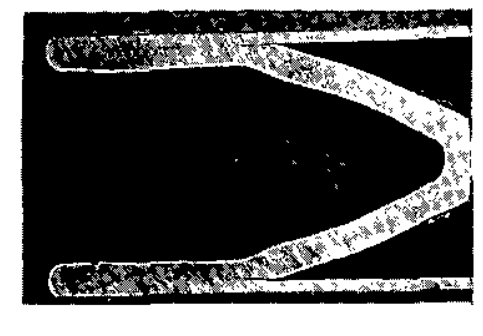
Neg. 18907
Mag. 1.9X
a. Lengthwise Section at End Plug

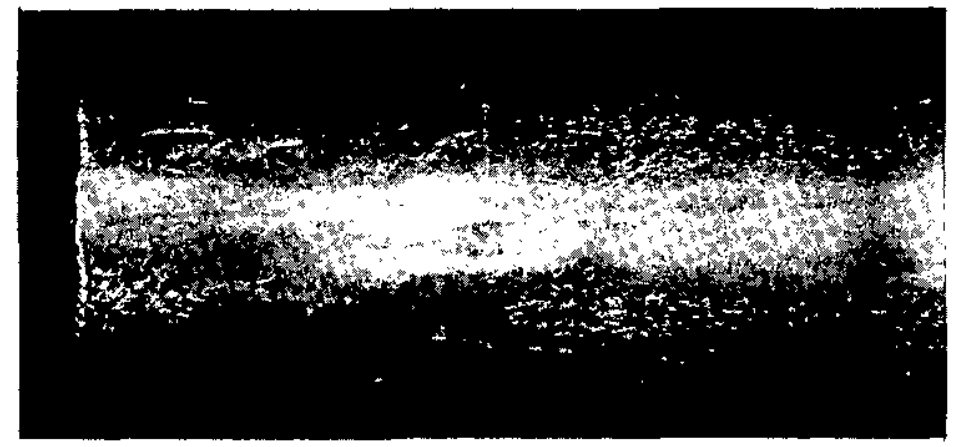

Nog. 18806

b. Exterior View at the Rod End

Mag. 2.5X

FIGURE 12 - ZIRCALOY-2-CLAD ROD SWAGED TO 50\% REDUCTION IN AREA

In the production of fuel rods, permanent end plugs would be economically preferable to temporary plugs that had to be replaced after swaging. A cross section of a promising design of permanent end plug is shown in Figure 13. The solid cylindrical portion can be made to form a special end fitting if desired. The ridge on the outside of the hollow portion is for alignment and welding purposes; the sheath butts against the ridge and is fusion welded to the ridge by the standard "Heliarc" technique. Exterior and sectional views of the end plug after swaging are shown in Figure 14. This type of end plug was satisfactory for stainless steel claddings as thin as 0.007 inch and for 0.022 -inch Zircaloy cladding. 


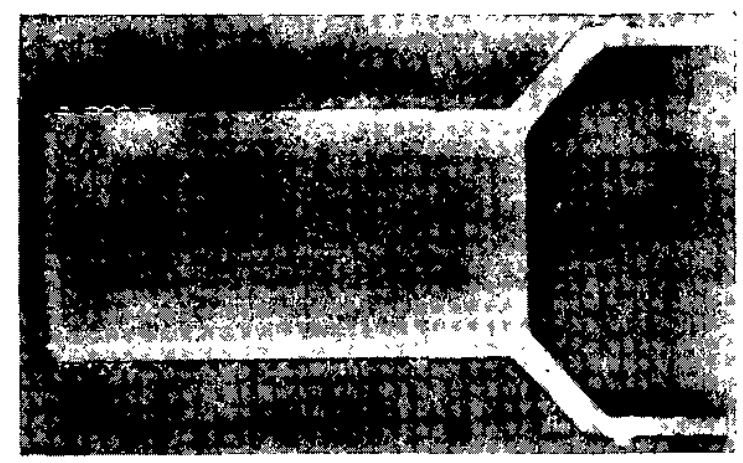

Nog. 18859

Mag. 2.3X

FIGURE 13 - LONGITUDINAL SECTION OF PERMANENT END PLUG BEFORE SWAGING

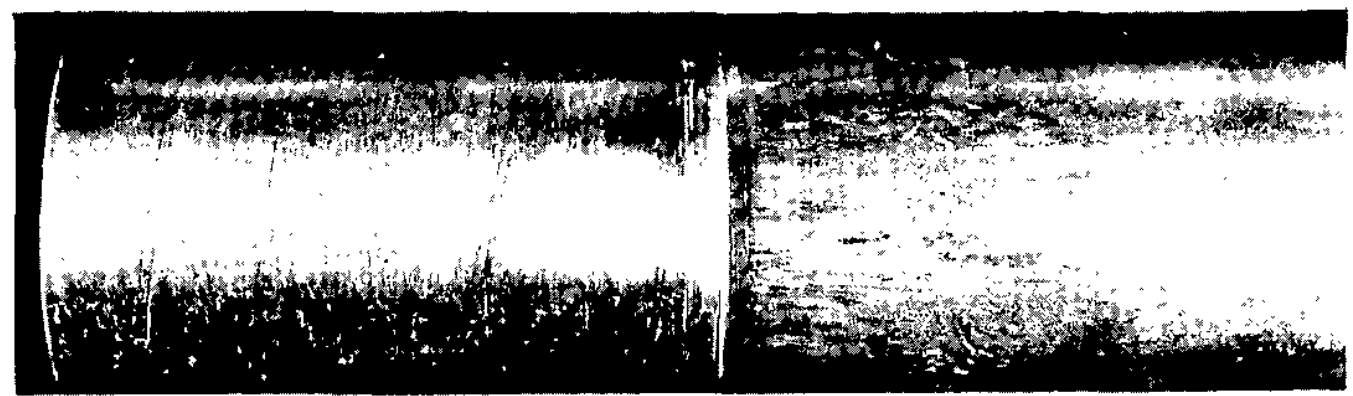

Nog. 18805

a. External Appearance, As-Swaged

Mag. 3.4X

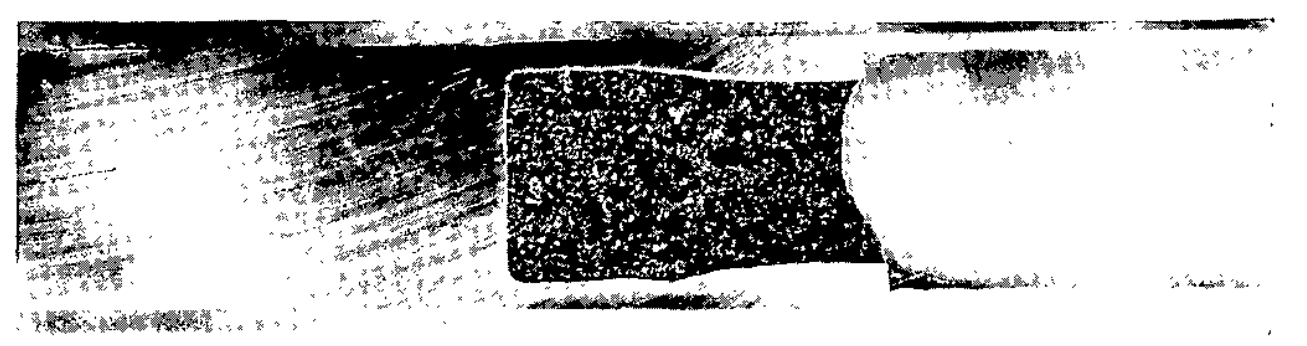

Neg. 18826

b. Longitudinal Soction

Mag. 2.5X

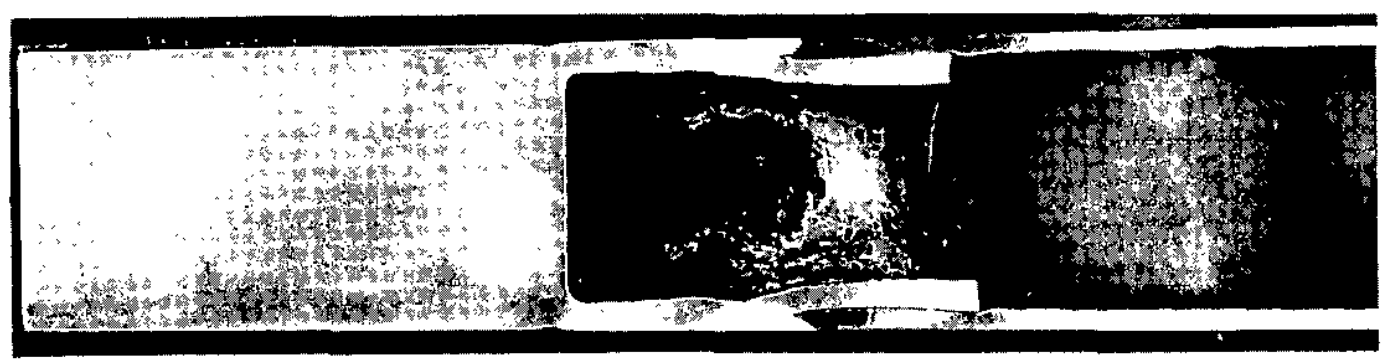

Neg. 18828

Mag. $2.5 X$

c. Longitudinal section efched to bring out the weld zone

FIGURE 14 - PERMANENT END PLUG AFTER SWAGING 


\section{SWAGING OF TUBES}

\section{TWO-DIE SWAGER}

In preliminary experiments with a two-dle swager, Fenn Model $6 \mathrm{~F}$, large diameter tubular elements were swaged to uranium oxide densities comparable to rod densities at intermediate area reductions. Swaging was limited to intermediate area reductions, approximately $30 \%$, because the two-die swager became very difficult to feed at higher reductions. In order to develop the techniques without contaminating the equipment, much of the swaging of tube shapes was done with cores of sand, alumina or a mixture thereof, and only a few tubes contalning uranium oxide were swaged.

A tubular element, consisting of $\mathrm{PWR}-\mathrm{grade} \mathrm{UO}_{2}$ contained in an annulus between 0.022 -inch-wall stalnless steel tubes of 2.80- and 2.00-inch diameter, was swaged through an area reduction of $32 \%$ to give a density of $61.5 \%$ of theoretical. This was essentially the same as the density obtained when a $3 / 4$-inch rod specimen was swaged to the same area reduction, as can be seen by reference to Figure 4. The sheath wall thickness, which was initially 0.021 inch, increased to 0.023 inch for the outer sheath, but was unchanged for the inner sheath, which was supported by the mandrel. The sheath behavior was in accord with expectations. The outer sheath thickened because it was being reduced in diameter with very little accompanying elongation; up to this reduction, the uranium oxide was still densifying without much resistance.

A similar tubular element containing fused uranium oxide pulverized to pass a 20 -mesh screen was swaged through an area reduction of $30 \%$ to an oxide density of $85 \%$ of theoretical. This density 1 s $3 \%$ lower than that obtained by swaging a 3/4-inch rod specimen through the same area reduction. The wall thickness behavior indicated that the specimen was farther along in the swaging pattern than was the PWR-grade tubular specimen. The outer sheath was 0.021 inch thick; presumably it had already thickened, and was now beginning to thin. The inner sheath was 0.020 inch thick; the oxide had begun to resist further densification and was working the inner sheath silghtly, as well as forcing the outer sheath to elongate.

Two views of a swaged tube are shown in Figure 15. The wrinkling of the unsupported sheath is apparent at the ends, as is a crack over the rubber end plug.

The inside diameter of each tube was supported by one of two types of mandrels: (1) an "anchored" mandrel that was fixed between the swaging dies but free to rotate, or (2) a "traveling" mandrel that moved with the tube. The traveling mandrels gave better results than the anchored mandrels. Tubes swaged using the anchored mandrel system were characterized by wrinkles in the inner sheath and occasional ovality of 
the outer sheath. The traveling mandrel system produced a better surface on the inner sheath, but the mandrel was difflcult to remove from the tube after swaging. Temporary end plugs of rubber or composition material were used; metal end plugs welded in place would have falled because of the unequal elongations of the inner and outer sheaths. End plugs of cast lead proved unsatisfactory.

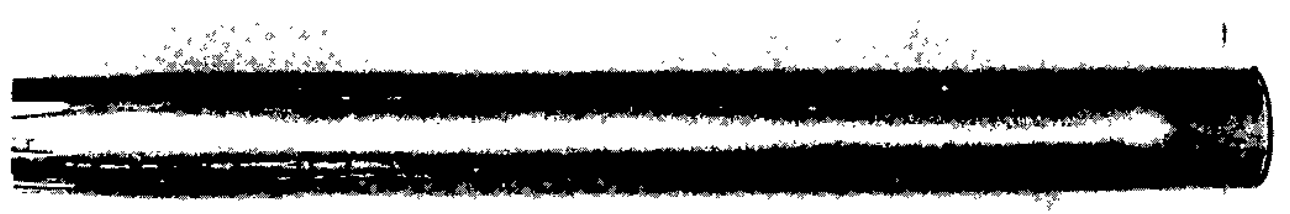

Neg. 20510

Mag. $0.2 X$

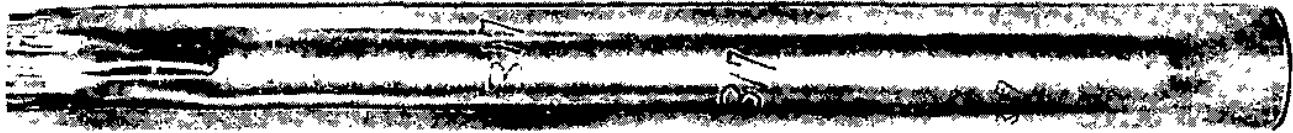

Neg. 20509

Mag. $0.2 x$

FIGURE 15 - SWAGED TUBULAR ELEMENT

The sheath wrinkled at the ends, which were not supported by core

material. The bottom view shows a crack over the rubber end plug.

\section{FOUR-DIE SWAGER}

As the next step in the development program, tubular elements loaded with sand and aluminum oxide were swaged in a four-die swager at the Fenn Company Plant in Newington, Connecticut. These tubes were reduced from 2.500 to 2.060 inches in outside diameter in 14 passes, while the inside diameter, a nominal 1.460 inches, was supported by a hollow steel traveling mandrel. The sheath material was Type 304 stainless steel, 0.022 inch thick.

The four-die swaging machine was superior to the two-die machine from the standpoints of ease of feeding the tube into the dies and of final surface quality of the sheaths. An area reduction of $52 \%$ was obtained with the four-die swager, compared with the maximum area reduction of $32 \%$ reached with the two-die swager.

Because of 1ts obvious operating advantages, the four-die swager was adopted as the principal tool for the fabrication of tubular oxide fuel elements. An extensive development program for the swaging of fused $\mathrm{UO}_{2}$ is underway and will be described in future reports. 


\section{ROLLING OF RODS}

The general pattern of loading, handling, and density behavior for a rolled rod was similar to that of a swaged rod. The rods were passed through grooved rolls of 16 -inch diameter at a speed of approximately $15 \mathrm{ft} / \mathrm{min}$. The roll parting was 0.063 inch. The maximum densities obtalned were slightly higher for PWR-grade $\mathrm{UO}_{2}$ specimens and slightly lower for fused oxide specimens than were the densities of swaged specimens with the respective oxides. Considerable difficulty was experienced in rolling the rods to area reductions comparable to those obtained by swaging. Rod diameters were reduced by $1 / 16$-inch decrements, and several passes through each groove were usually required.

The maximum densities obtalned in the rolled rods were $78 \%$ of theoretical for PWR-grade oxide and $89 \%$ of theoretical for fused uranium oxide; these compared with 75 and $93 \%$, respectively, for swaged rods. The rolled PWR-grade oxide had a sheath of 0.145 -inch-thick stainless steel, whereas the swaged rod had a 0.065 -inch-thlck clading. The fused oxide specimen was preswaged from 0.750 - to 0.688 - Inch diameter, then rolled to 0.530 -inch diameter, at which stage it cracked.

The effects of sheath materials and dimensions on $\mathrm{UO}_{2}$ densities in rolled rods were roughly analogous to the behavior observed in swaged rods. The data for rolled rods are much less extensive, however. Maximum densities obtained by various combinations of treatments and materials are listed and compared with swaging results in Table VII. The specimens sheathed in carbon steel reached slightly lower oxide densities than did those sheathed in stainless steel. A composite sheath, stainless steel within carbon steel, conferred no advantages.

TABLE VII

Density of $\mathrm{UO}_{2}$ in Rolled Rods

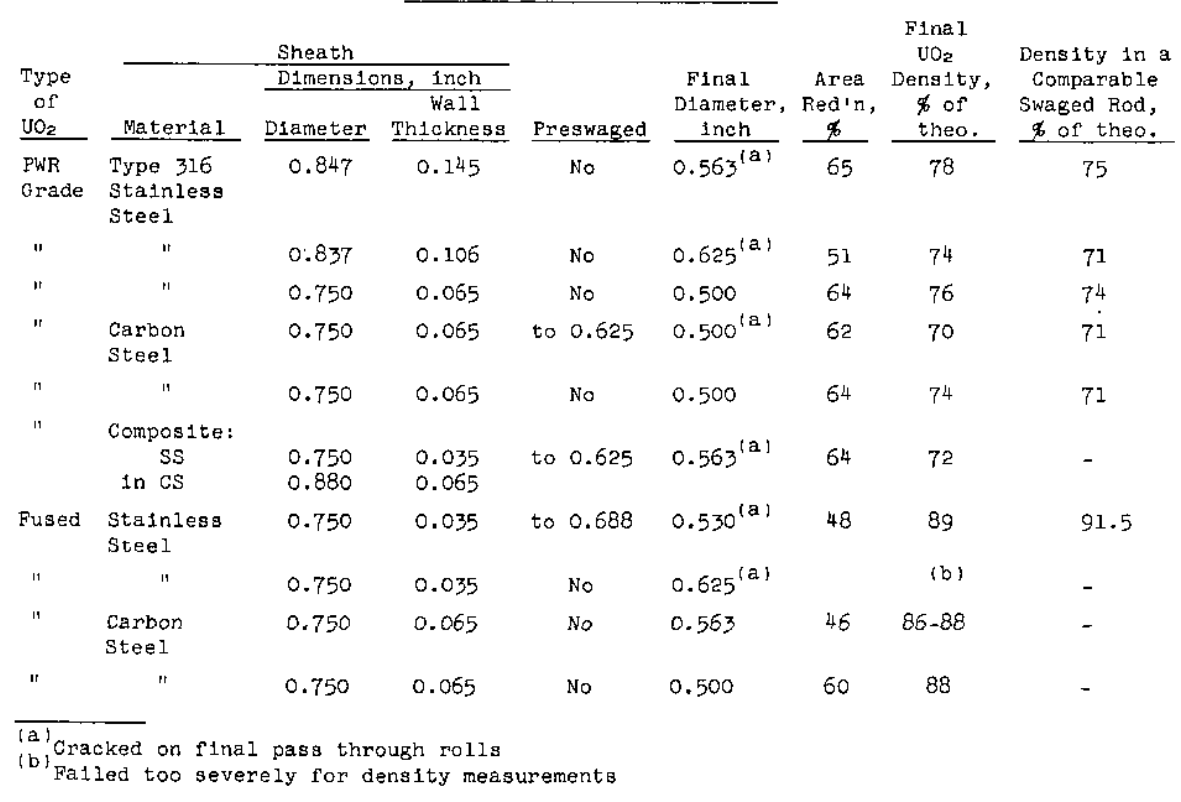


Many of the rods bowed, finned, and split during rolling. Of the first 25 rods rolled, 22 were cracked along the longitudinal direction. All rods exhibited severe finning, ovality, variations in wall thickness, and warp. A group of typical rolied rods is shown in Figure 16; a closeup of a split sheath appears in Figure 17.

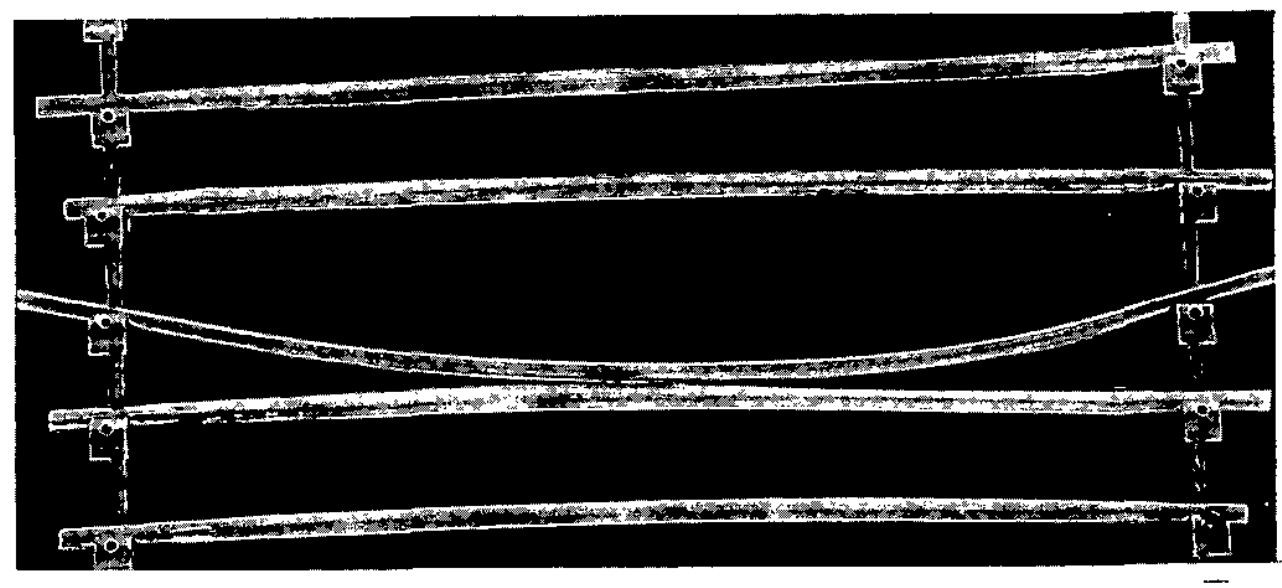

Neg. 17353

Mag. $\overrightarrow{0.16 x}$

FIGURE 16 - ROLLED ROD ELEMENTS

$\mathrm{Al}_{2} \mathrm{O}_{3} \mathrm{Clad}$ in Stainless Steel

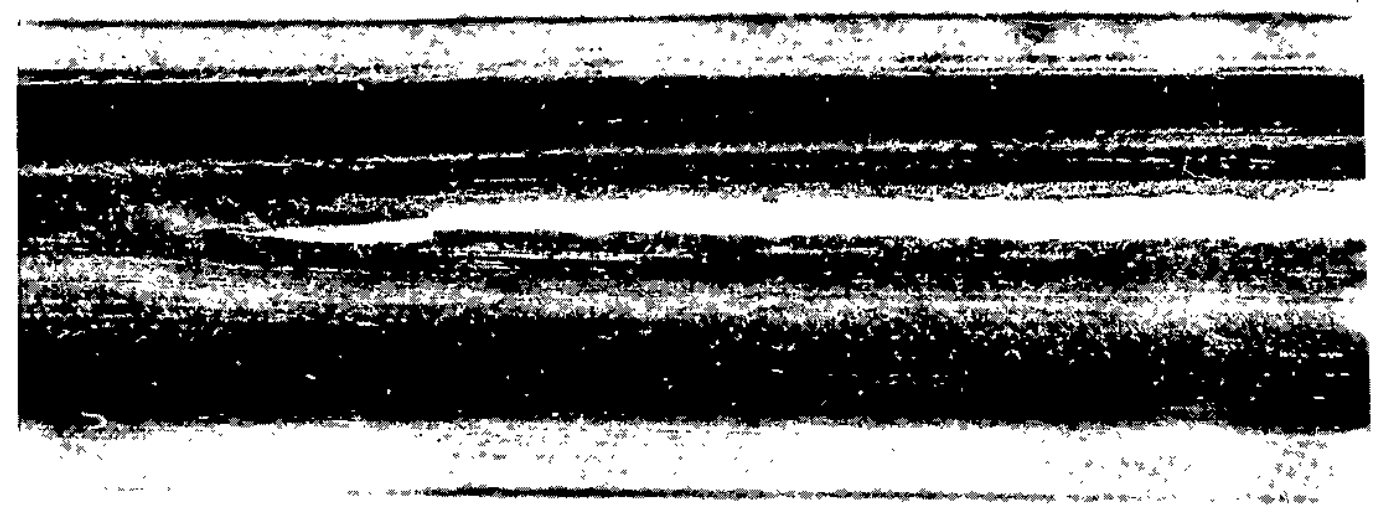

Neg. 20515

$\operatorname{Mag} \cdot 3.4 X$

FIGURE 17 - SHEATH FAILURE OF A ROLLED ROD $\mathrm{Al}_{2} \mathrm{O}_{3} \mathrm{Clod}$ in Stainless Steel 
Figure 18 shows cross sections of sheaths for 0.065 - and 0.035 -inchwall specimens. The 0.035 -inch-wall specimen shows the fins that were produced by the groove ovality and the roll parting, or relief space between the rolls. The 0.065 -inch-wall specimen was rolled repeatediy through the same groove in an attempt to improve the external appearance. Even then the final shape was somewhat oval, and there was a thickening of the sheath in two places caused by the superficlal removal of fins formed on a previous pass. A slight improvement was achieved with a composite sheath as shown in Figure 19; the outer sheath was finned severely, but the inner sheath was less so.

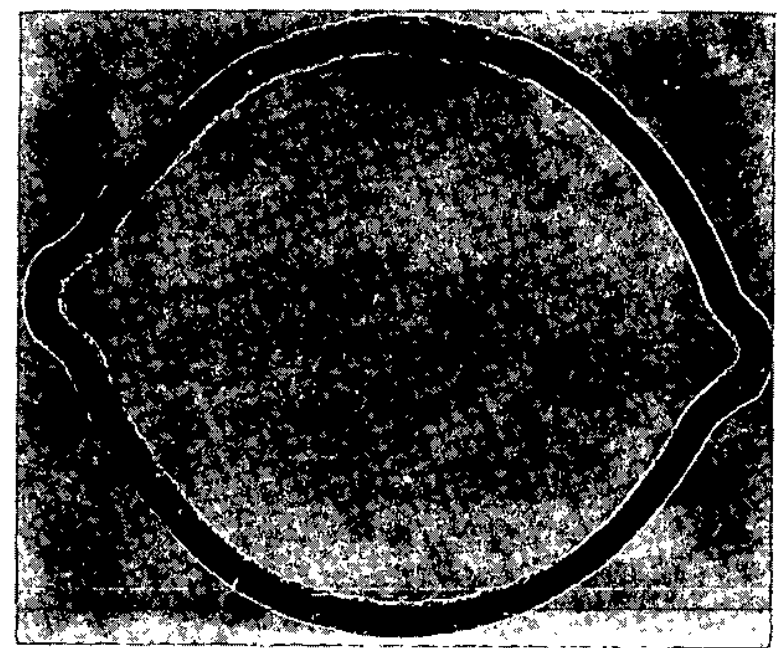

Nog. 17596
Mog. 4.25X

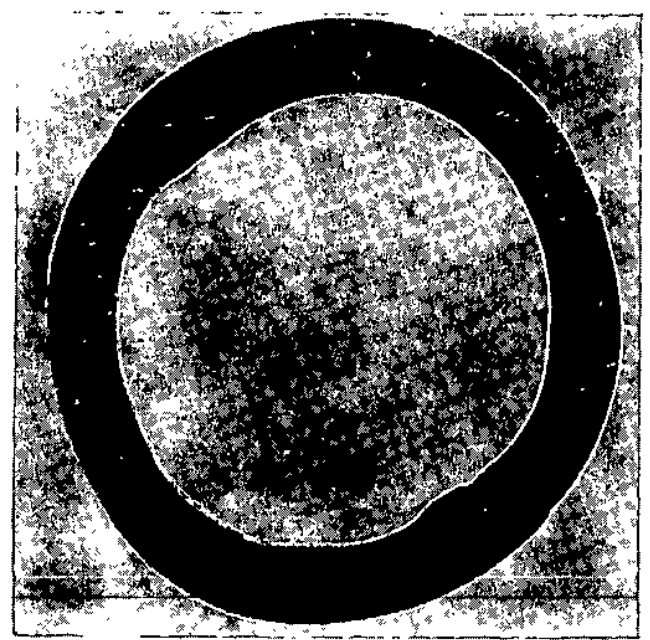

Nog. 17597

Mog. $4.25 X$

FIGURE 18 - CROSS SECTIONS OF SWAGED-AND-ROLLED RODS

Cross sections of sheaths from rod elements were formed by swaging followed by rolling. The core material has been removed and the sheaths mounted for inspection.

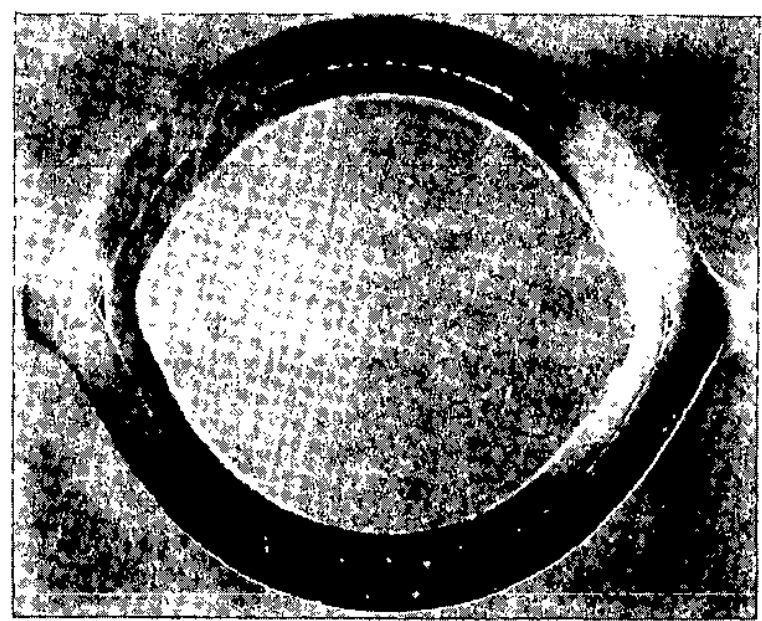

Nog. 18052

Mag. $3.25 \mathrm{X}$

FIGURE 19 - CROSS SECTION OF ROLLED ROD - COMPOSITE SHEATH Cross Section of a Rollod Rod with a Composite Sheoth: Carbon Steel Outer Sheath, Stainless Steel Inner Sheath 


\section{ROLLING OF RIBBONS}

Ribbon shapes were formed by loading uranium oxide into metal tubing and rolling it flat between plain rolls. The specimens were passed through the 16-inch-diameter rolls at a speed of $10 \mathrm{ft} / \mathrm{min}$. Roll spacing was reduced by $0.050-1$ nch decrements in the early stages of reduction, and by 0.025 -1nch decrements in the later stages.

The uranium oxide density in the rolled ribbons increased with area reduction more rapidly at low reductions than did similar swaged rods, but at high reductions the density was lower in comparison. Figure 20 lilustrates this density behavior for PWR-grade oxide sheathed in Type 316 stainless steel; the density was still increasing slightly at the highest reduction obtained, 56\%. Further reductions were prevented by specimen fallures, usually over an end plug.

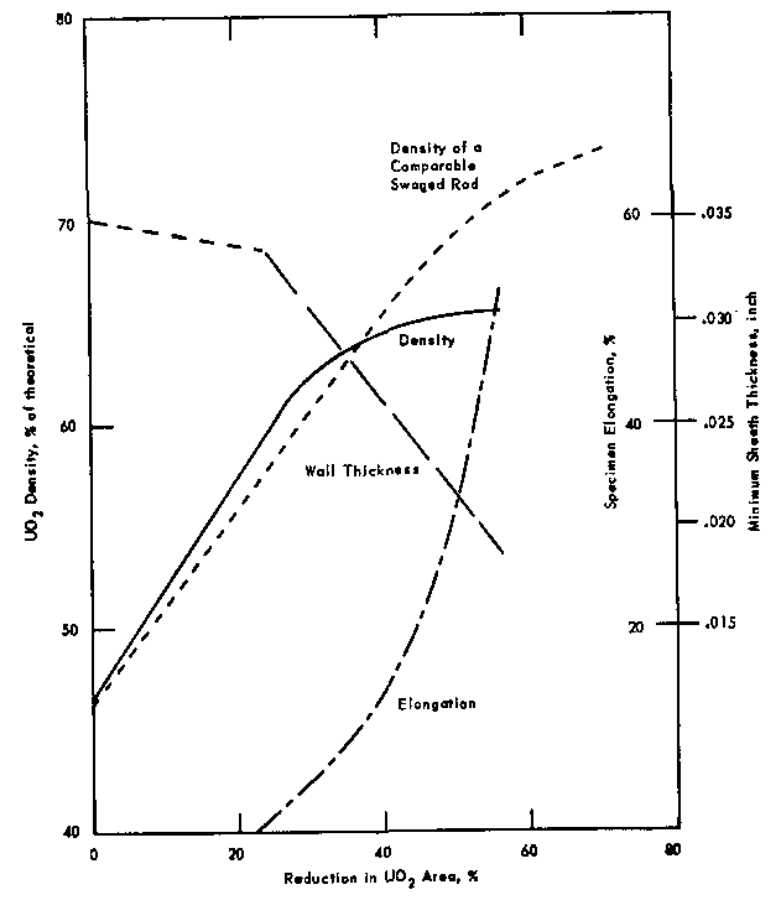

FIGURE 20 - ROLLING BEHAVIOR OF RIBBONS - PWR-GRADE $\mathrm{UO}_{2}$

Type 316 Stainless Stool Cladding; Initial Rod Diameter $=0.750$ inch, Wall Thickness $=0.035$ inch

Rolled ribbons of PWR-grade uranium oxide in stainless steel sheathing reached higher final densities when preswaged in rod form than when not preswaged, but in neither case were the densities as high as for rods swaged to an equivalent area reduction.

Specimens initially $3 / 4$ inch in diameter with an 0.035 -inch sheath thickness reached a density of $65.5 \%$ of theoretical when flat-rolled to an area reduction of $56 \%$, but reached $71 \%$ of theoretical when swaged through the same area reduction in rod form. A specimen rollflattened to a total reduction of $56 \%$ after being preswaged through 
a $46 \%$ area reduction in rod form reached a density of $69 \%$, intermediate between those rolled only and those swaged only. A slight increase in final density was obtained by preswaging the end portions of the specimens before rolling them flat; this increase was about 1\% of theoretical, half that given by preswaging the entire specimen. Whether the end plugs were rubber or metal backed by rubber did not affect the density. Specimens preswaged in rod form and then rolied flat have, of course, different final dimensions in cross section than specimens rolled to the same total area reduction without preswaging.

Ribbons of fused $\mathrm{UO}_{2}$ in stainless steel were rolled to a maximum oxide density of $86.5 \%$ of theoretical, which was about $5 \%$ less than the density normally reached in swaged rods of simflar material. Reductions beyond $40 \%$ caused a decrease in oxide density, as shown in Figure 21.

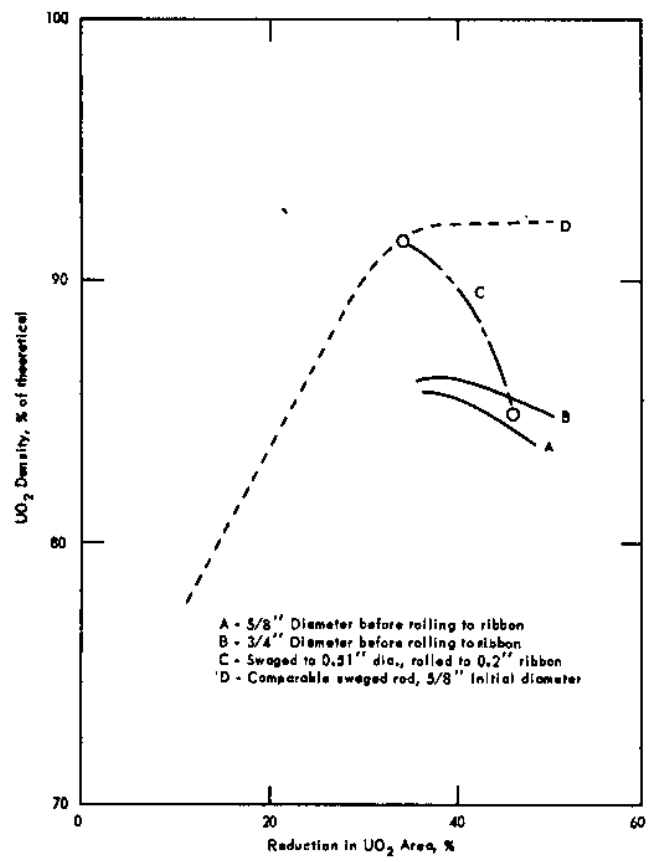

FIGURE 21 - ROLLING BEHAVIOR OF RIBBONS - FUSED $\mathrm{UO}_{2}$ Minus 20-Mesh, Grade 2, Fusod $\mathrm{UO}_{2}$, Sheothod in Type 316 Stainless Steol 
A specimen swaged to a density of $91 \%$ of theoretical at an area reduction of $36 \%$, and then flattened by rolling, suffered a density decrease to $84 \%$ of theoretical, even though the total area reduction had increased to 47\%. During flattening from a rod of 0.51 -inch diameter to a ribbon only 0.2 inch thick, the sheath thickness was reduced from 0.034 to 0.019 inch at the thinnest point, the center of the flat face. The decrease in density probably resulted from small volds Induced by the forced flow of the oxide and from the effect of sheath springback. There were no appreciable differences in final density between rolled ribbons with preswaged ends and those without preswaged ends for the specimens containing the fused oxide. A straticulate structure appeared in the oxide at about $30 \%$ area reduction. Figure 22 shows the stratification in the cross sections of two rolled ribbons; the onset of the phenomenon is just detectable in the upper photograph (area reduction 31\%, thickness 0.34 inch), but is quite pronounced in the lower one (area reduction 52\%, thickness 0.205 inch). Several changes in behavior occur at approximately $30 \%$ area reduction; the most significant, perhaps, is the rapid change in slope of the curve of density versus area reduction. At a slightly lower reduction, about 25\%, wall thinning and specimen elongation first become appreciable (see Figure 20); these indicate, respectively, the increasing resistance of the oxide to further densification and the onset of lengthwise flow of the powder. Relevant data are given in Table VIII.

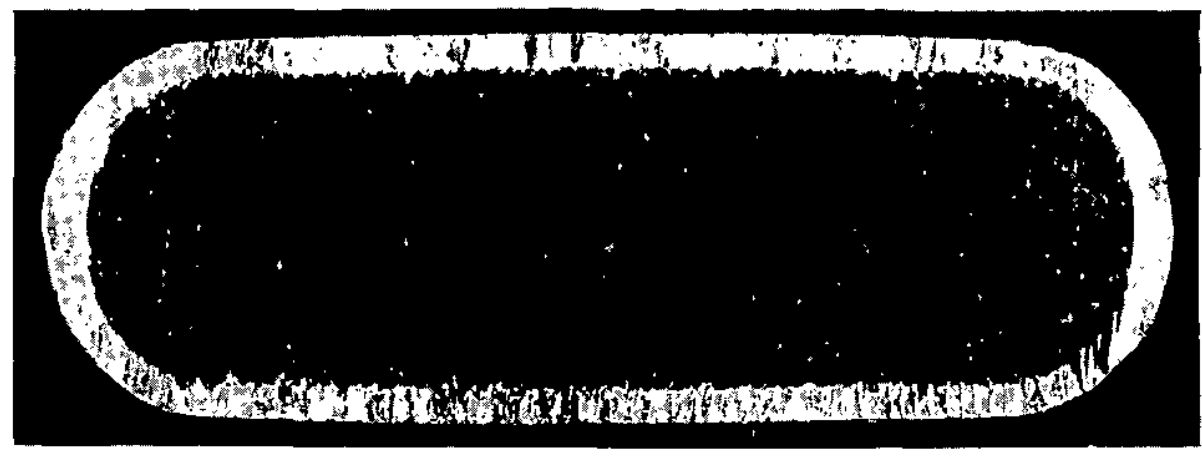

Neg. 18049

$$
\begin{aligned}
& \text { a. } \mathrm{UO}_{2} \text { Density }=65 \% \text { of Theoretical } \\
& \mathrm{UO}_{2} \text { Area Reduction }=31 \%
\end{aligned}
$$

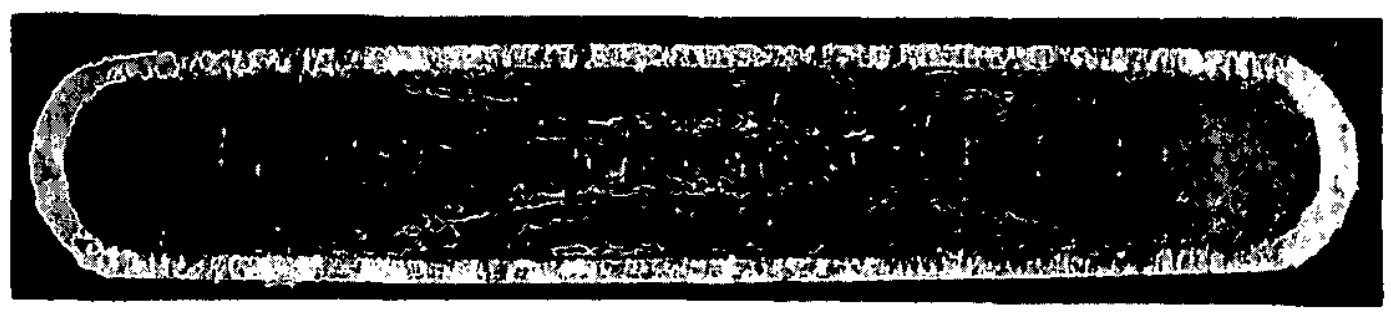

Neg. 18050

b. $\mathrm{UO}_{2}$ Density $=69 \%$ of Theoretical

Mag. 4.25X

$\mathrm{UO}_{2}$ Area Reduction $=52 \%$

FIGURE 22 - CROSS SECTIONS OF ROLLED RIBBONS

PWR - Grode $\mathrm{UO}_{2}$ in Type 316 Stoinless Steel Rolled Flot

from Rod Shapes Initially 3/4 Inch in Outside Diameter 
TABLE VIII

Stratification in Flat-Rolled Spec1mens

PWR-grade $\mathrm{UO}_{2}$ in Type 316 sta1nless steel

Inttial diameter $=0.750$ inch

Inst1al wall thickness $=0.035$ inch

\begin{tabular}{|c|c|c|c|c|c|}
\hline $\begin{array}{c}\text { Area } \\
\text { Reduction, } \\
\$ \\
\end{array}$ & $\begin{array}{l}\text { Rate of Change } \\
\text { of Density (a) }\end{array}$ & $\begin{array}{c}\text { Ribbon } \\
\text { Thickness, } \\
\text { 1nch } \\
\end{array}$ & $\begin{array}{l}\text { Sheath (b) } \\
\text { Thickness, } \\
\text { Inch }\end{array}$ & $\begin{array}{c}\text { Specimen } \\
\text { Elongation, } \\
\varnothing \\
\end{array}$ & $\begin{array}{c}\text { Straticulate } \\
\text { Structure }\end{array}$ \\
\hline 25 & 0.53 & 0.39 & 0.034 & 0 & None \\
\hline 30 & 0.37 & 0.34 & 0.030 & 7 & Slight \\
\hline 38 & 0.18 & 0.29 & 0.028 & 10 & Үев \\
\hline 47 & 0.08 & 0.24 & 0.022 & 25 & Yes \\
\hline 51 & 0.06 & 0.21 & 0.021 & 35 & Pronounced \\
\hline 56 & 0.05 & 0.18 & 0.019 & 52 & Pronounced \\
\hline
\end{tabular}

It is not certain whether the layer structure and the abrupt slope change of the density curve were caused by lengthwise movement of the powder or by springback of the sheath after rolling, but the latter is favored by the following consideration. Swaged rods have elongations comparable to rolled ribbons, but they do not exhibit the rapid change of slope in the density curve. Therefore, the basic difference between swaged rods and rolled ribbons may lie in the lesser sheath springback that is characteristic of the rod shape.

A slight effect of initial diameter on final density was observed. The smaller inftial diameters gave higher flnal densities with PWRgrade uranium oxide (Figure 23), as was the case with swaged rods.

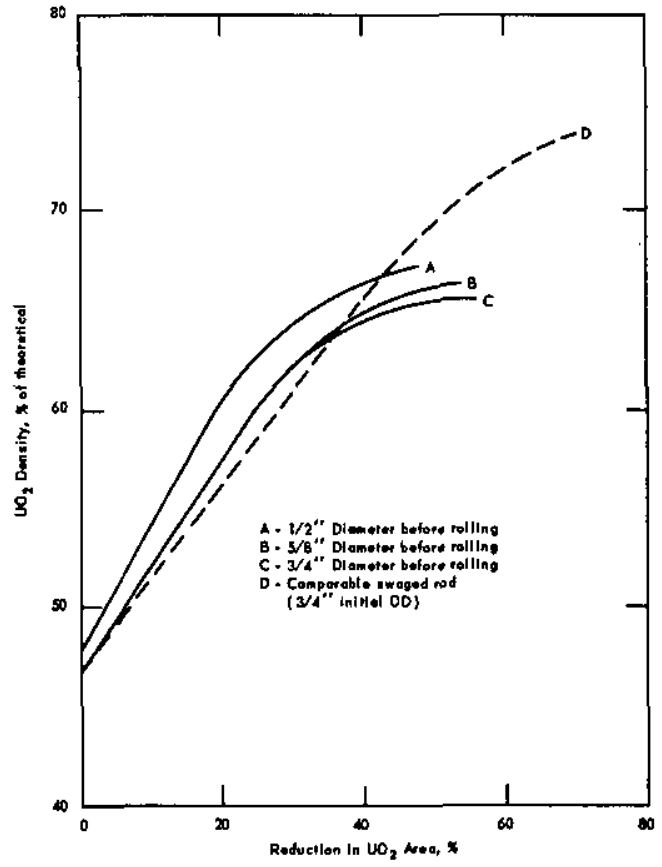

FIGURE 23 - EFFECT OF ROD DIAMETER ON UO 2 DENSITY IN ROLLED RIBBONS PWR-Grade $\mathrm{UO}_{2}$ in Type 316 Stainless Steel Tubing; Initial Wall Thickness $=0.035$ Inch 
The reverse appeared to be true for fused uranium oxide (Figure 2l), but this may be because the specimens of 5/8-inch initial diameter had already passed their peak densities at the area reductions shown on the graph. No data were taken for area reductions less than $36.5 \%$.

The rlbbons tended to develop camber - bending in the plane of the ribbon - at the large area reductions, typically at reductions greater than 35\%. Bow was seldom a problem.

The ribbons could be twisted after being annealed to restore ductility. Figure 24 shows a section of ribbon twisted through approximately 180 degrees per foot. Twisting without prior annealing required much more force and produced a very irregular pitch. The twisting was performed with a vise and a large wrench.

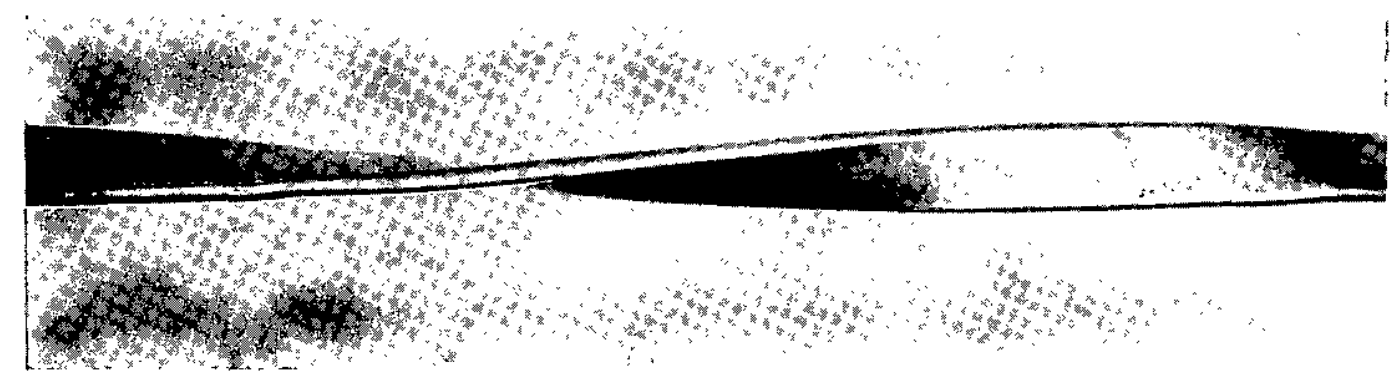

Neg. 18009

Mag. $0.44 X$

FIGURE 24 - TWISTED RIBBON ELEMENT

A Twisted Ribbon of PWR - Grade Oxide in Stainless Steel. The Specimen was Rolled Flat from a Rod Shape, Annealed, and Twisted in a Vise.

Uranium oxide densities within the twisted ribbons could not be measured accurately because the compacted oxide, being broken up by the twisting movement, was inadequately retained within the small sections that were cut for evaluation.

\section{COEXTRUSION OF RODS}

Experimental coextrusions were made of fused uranium oxide sheathed in aluminum. Aluminum sheaths were used to simplify the study of the low temperature extrusion behavior of $\mathrm{UO}_{2}$, and not because $\mathrm{Al}$ cladding was desired in the final product. A consistently successful extrusion rat1o was $6.6: 1$, which resulted in aluminum-clad oxide rods of 0.525-inch nominal diameter. The temperature of extrusion was 445 to $480^{\circ} \mathrm{C}$. The billets were extruded at either 0.5 or 3 inches per minute with no apparent differences in the results; the force on the $1-3 / 8$-inch-diameter ram was 55,000 pounds (a pressure of $37,0001 \mathrm{~b} / \mathrm{in}^{2}$ ) at the beginning of the extrusion. The extrusion dies were of the streamline-flow type with a $90^{\circ}$ included angle in the die cone. The extrusion assembly was a small experimental design that was intended 
for use with a mechanical testing machine. Exploded and assembled views of the extrusion biliets are shown in Figure 25, and typical as-extruded rods are shown in Figure 26 .

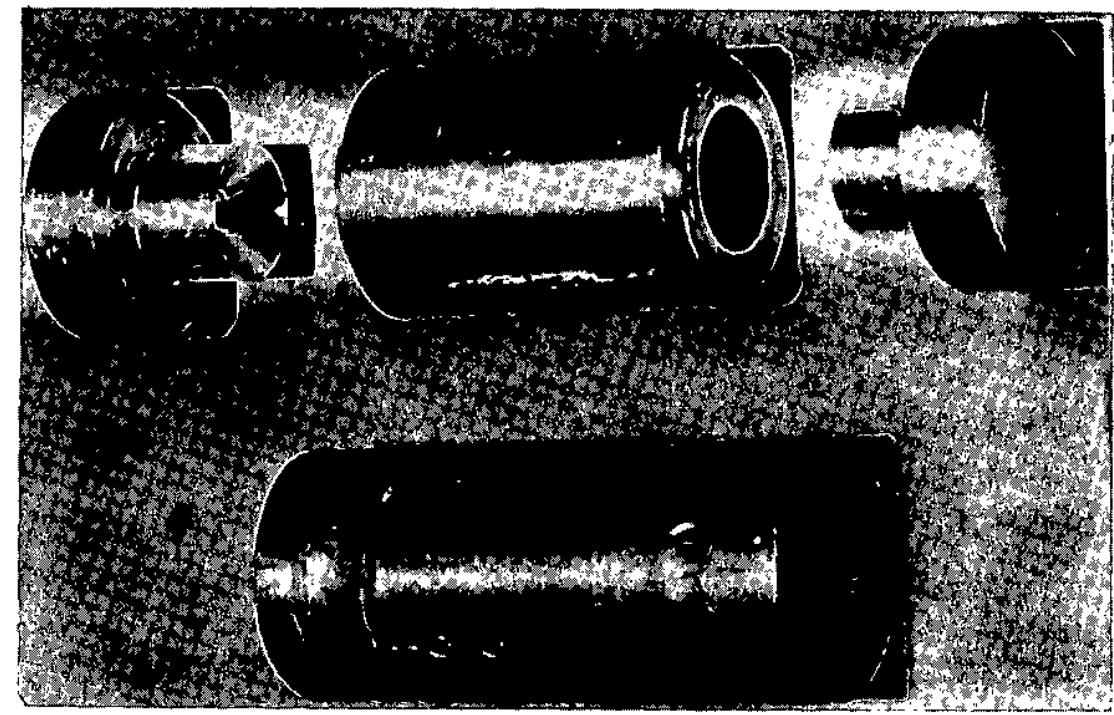

Neg. 20508

Mag. $0.65 \mathrm{X}$

FIGURE 25 - COEXTRUSION BILLETS

Exploded and Assembled Views of Composite Billets

for Coextrusion of $\mathrm{UO}_{2}$ in an Aluminum Alloy Sheath

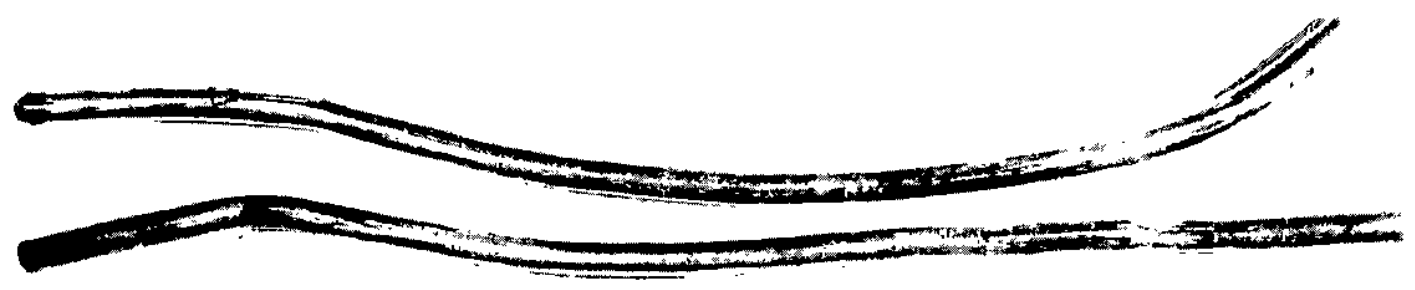

Neg. 20507

Mag. $0.25 \mathrm{X}$

a. Over-all View

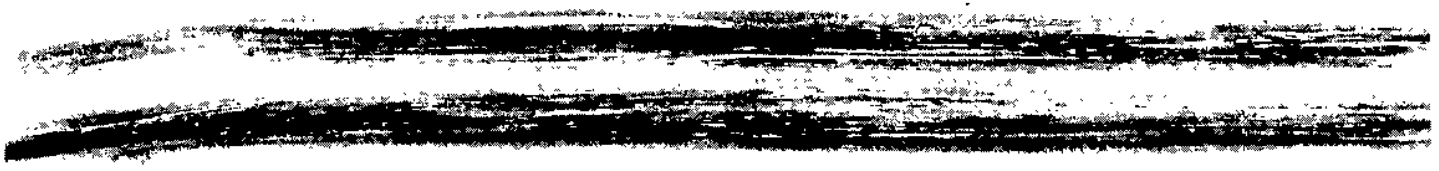

Nog. 18380

Mag. 1.1X

b. Close-up View

FIGURE 26 - TYPICAL COEXTRUDED RODS

Typical As- Extruded Rods. Fused $\mathrm{UO}_{2}$ Clad in Aluminum Alloy 
The final densities of the uranium oxide were low compared to those obtained by swaging or rolling of fused oxide. The initial and final densities of several specimens, together with the particle sizes of the oxide, are given in Table IX. The larger particle sizes produced higher densities, but they also caused greater roughening of the inner surface of the cladding.

\section{TABLE IX}

Density of $\mathrm{UO}_{2}$ in Coextruded Rods

\begin{tabular}{|c|c|c|}
\hline \multirow{2}{*}{$\begin{array}{l}\text { Sleve sqze } \\
\text { of } \mathrm{UO}_{2}\end{array}$} & \multicolumn{2}{|c|}{ Density, of theoretical } \\
\hline & Initial & Fina1 \\
\hline-16 & 52.3 & 75.8 \\
\hline-20 & 50.3 & 72.9 \\
\hline-40 & 52.3 & 70.9 \\
\hline-120 & 49.1 & 71.2 \\
\hline-200 & 44.0 & 69.2 \\
\hline
\end{tabular}

(a) All particles that passed the sieve number listed (U. S. Standard Sieve Sizes) were used.

A temperature high enough to give some plastic deformation of the oxide, $800^{\circ} \mathrm{C}$ or above, (15) would probably be required to achieve a high oxide density by means of coextrusion.

Sheath thickness exhibited a cyclic variation along the rod length as well as minor variations at a given cross section. A radiograph of four extruded rods is shown in Figure 27, and a cross-section of a rod is shown in Figure 28.

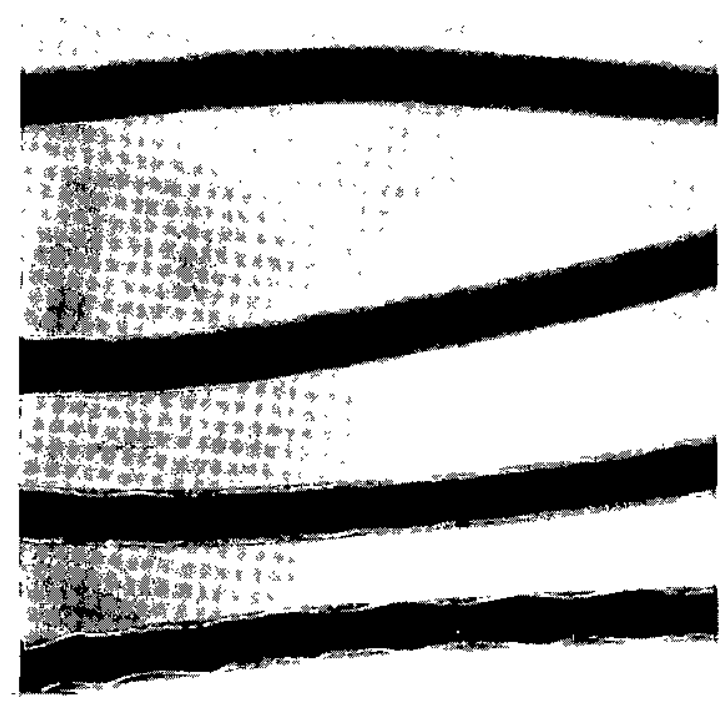

Film No. 707 D

Mag. 0.5X

FIGURE 27 - RADIOGRAPHS OF COEXTRUDED RODS Fused $\mathrm{UO}_{2}$ Clad in Aluminum Alloy 
The sheath thicknesses of the extruded rods varied from 0.14 to 0.17 inch, and the outside diameter varled from 0.50 to 0.52 inch. The nonuniformities in the core and sheath were probably caused by a pulsating flow of the $\mathrm{UO}_{2}$ powder through the die. During the minima of the oxide flow the aluminum sheathing moved in to fill the deficiency in the core, causing the sheath to vary in thickness.

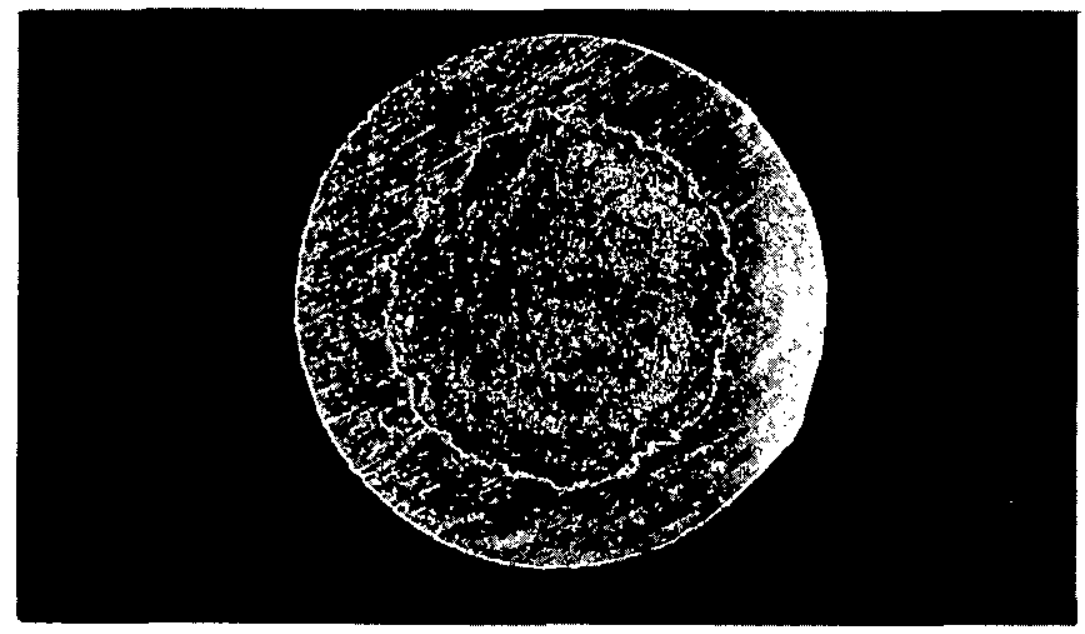

Neg. 20513

Mag. 4.2X

FIGURE 28 - CROSS SECTION OF COEXTRUDED ROD Fused $\mathrm{UO}_{2}$ Clad in Aluminum Alloy

Aluminum alloys employed as cladding materials included Types 1100 , 5052, and 5154. Rods clad with the harder alloys, 5052 and 5154, had better surfaces and smaller core end defects than did rods clad with 1100 aluminum.

Attempts to extrude with extrusion ratios of $15: 1$ and $10: 1$ resulted in fallure of the extrusion assembly. In a fallure at a 15:1 extrusion rat10 the uranium oxide reached a density of $90 \%$ of theoretical in the unextruded part of the billet but only $75 \%$ in the extruded portion. In such cases, the force on the ram increased during the course of the extrusion until the fallure occurred. The ram force decreased slightly during the successful extrusion at a ratio of $6.6: 1$.

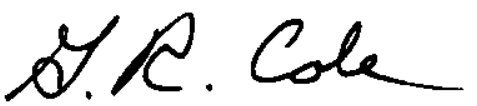

G. R. Cole

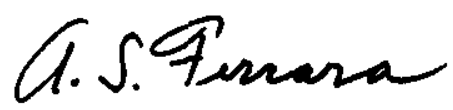

A. S. Ferrara

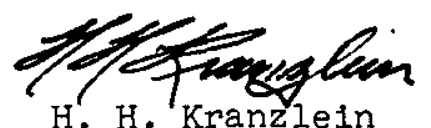

Pile Materials Division 


\section{BIBLIOGRAPHY}

1. Elchenberg, J. D., et al., Effects of Irradiation on Bulk Uranium Diox1de, Westinghouse Electr1c Corp., WAPD-183, October 1957. (TID-7546, pp. 442-515)

2. Robertson, J.A. I., et al., "Behavior of Uranium Oxide as a Reactor Fuel", Proc. U. N. Intern. Conf. Peaceful Uses Atomic Energy, 2nd, Geneva, 1958, 6, 655-76 (1958). P/193

3. Materials for Nuclear Reactors, Bernard Kopelman, ed. New York: McGraw Hill (1959).

4. Aronson, S., "Oxidation of $\mathrm{UO}_{2}$ in Water Containing Oxygen". Bettis Technical Review. Reactor Metallurgy, Westinghouse Electric Corp., WAPD-BT-10, pp. 93-5, October 1958.

5. Kingery, W. D., et al., "Thermal Conductivity: $x$, Data for Several Pure Oxide Materiais Corrected to Zero Porosity". J.Am. Ceram. Soc. 37, 107 (1954).

6. Hedge, J. C., Measurement of Thermal Conductivity of Uranium Oxide, Illino1s Inst1tute of Technology, Chicago, Armour Research Foundation, AECU-3381, September 1956.

7. Scott, R., Thermal Conductivity of $\mathrm{UO}_{2}$, Atomic Energy Research Establishment, Harwell, Berks., AERE M/R 2526, March 1958.

8. Ross, A. M., A Literature Survey on the Measurement of Therma1 Conductivity of Several Solids Including Uranium Dioxide, Atomic Energy of Canada, Ltd., CRFD-762, March 1958.

9. Stenquist, D. R. and An1cett1, R. J., "Fabrication of Ceramic Fuel Elements by Swaging". Nuclear Metallurgy 2, Symposium on the Fabrication of Fuel Elements (1958).

Also the periodic reports from the Hanford Atomlc Products operation of the General Electric Company.

10. Patterson, D. L. and Chalder, G. H., The Integral Fabrication of Uranium Dioxide Fuel Elements by Rotary Swaging, Atomic Energy of Canada, Ltd., CRFD-759, June 1959.

Also the perlodic reports from the Chalk River Laboratory of Atomic Energy of Canada, Ltd.

11. Clayton, J.C. and Aronson, S., "Densities of Uranium Oxide in the Region $\mathrm{UO}_{2}-\mathrm{U}_{4} \mathrm{O}_{9} "$. Bettis Technical Review. Reactor Metallurgy, Westinghouse Electrical Corp., WAPD-BT-10, pp. 96-100, October 1958.

12. Stenquist, D. R., Hanford Atomic Products Operation. Private Communication. 
13. Scott, R., The Warm-Pressing $\left(800^{\circ} \mathrm{C}\right)$ of Uranium Dioxide and Uranium Dioxide - Metal Mixtures, Atomic Energy Research Establishment, Harwel1, Berks., AERE M/R-2396. September 1957.

14. Belle, J. and Lustman, B., Propert1es of Uranium Dioxide, Westinghouse Electric Corp., WAPD-184, September 1957. (TID-7546, pp. 616-716).

15. Hall, A. R., Scott, R., and Wllliams, J., The Plastic Deformation of Uranium Oxides Above $800^{\circ} \mathrm{C}$, Atomic Energy Research Establishment, Harwell, Berks., AERE M/R-2648, August 1958. 